\title{
Greater role for Atlantic inflows on sea-ice loss in the Eurasian Basin of the Arctic
} Ocean

Igor V. Polyakov ${ }^{1 *}$, Andrey V. Pnyushkov ${ }^{2}$, Matthew B. Alkire ${ }^{3}$, Igor M. Ashik ${ }^{4}$, Till M. Baumann $^{1}$, Eddy C. Carmack ${ }^{5}$, Ilona Goszczko ${ }^{6}$, John Guthrie $^{3}$, Vladimir V. Ivanov ${ }^{7}$, Torsten Kanzow ${ }^{8}$, Richard Krishfield ${ }^{9}$, Ronald Kwok ${ }^{10}$, Arild Sundfjord ${ }^{11}$, James Morison $^{3}$, Robert Rember ${ }^{2}$, Alexander Yulin ${ }^{4}$

1 International Arctic Research Center and College of Natural Science and Mathematics, University of Alaska Fairbanks, 930 Koyukuk Drive, Fairbanks, AK, 99775, USA

2 International Arctic Research Center, University of Alaska Fairbanks, 930 Koyukuk Drive, Fairbanks, AK, 99775, USA

3 Polar Science Center, Applied Physics Lab, University of Washington, 1013 NE $40^{\text {th }}$ Street, Seattle, WA 98105, USA

4 Arctic and Antarctic Research Institute, 38 Bering Street, St. Petersburg, 199397, Russia

5 Institute of Ocean Sciences, Fisheries and Oceans Canada, 9860 West Saanich Road, Sidney, BC, V8L 4B2, Canada

6 Institute of Oceanology, Polish Academy of Sciences, Powstancow Warszawy 55, 81-712 Sopot, Poland

7 International Arctic Research Center, University of Alaska Fairbanks, 930 Koyukuk Drive, Fairbanks, AK, 99775, USA, Hydrometeorological Center of Russia, 11-13, B, Predtechensky per., Moscow, 123242, Russia and Arctic and Antarctic Research Institute, 38 Bering Street, St. Petersburg, 199397, Russia

8 Alfred-Wegener-Institute, Helmholtz Centre for Polar and Marine Research, Bussestraße 24, 27570 Bremerhaven, and Department of Physics and Electrical Engineering, Bremen University, Otto-Hahn Allee, 28334 Bremen, Germany

9 Woods Hole Oceanographic Institution, 22 Water St, Woods Hole, MA 02543, USA

10 Jet Propulsion Laboratory, California Institute of Technology,4800 Oak Grove Drive Pasadena, CA 91109, USA

11 Norwegian Polar Institute, Fram Centre, N-9296 Tromsø, Norway

*Corresponding author: Igor Polyakov, 907-474-2686, igor@iarc.uaf.edu 
43 Arctic sea-ice loss is a leading indicator of climate change and can be attributed, in large

44 part, to atmospheric forcing. Here we show that recent ice reductions, weakening of the

45 halocline, and shoaling of intermediate-depth Atlantic Water layer in the eastern Eurasian

46 Basin have increased winter ventilation in the ocean interior, making this region

47 structurally similar to that of the western Eurasian Basin. The associated enhanced

48 release of oceanic heat has reduced winter sea-ice formation at a rate now comparable to

49 losses from atmospheric thermodynamic forcing, thus explaining the recent reduction in

50 sea-ice cover in the eastern Eurasian Basin. This encroaching "atlantification" of the

51 Eurasian Basin represents an essential step toward a new Arctic climate state, with a

52 substantially greater role for Atlantic inflows. 
54 Over the last decade, the Arctic Ocean has experienced dramatic losses of sea-ice loss in

55 the summers, with record-breaking years in 2007 and 2012 for both the Amerasian Basin

56 and the Eurasian Basin (EB). More remarkably, the eastern EB has been nearly ice-free

57 ( $<10 \%$ ice coverage) at the end of summer since 2011 (Fig. 1). Most sea ice-mass loss

58 results from summer solar heating of the surface mixed layer (SML) through cracks in the

59 ice and open water, and consequent melting of the lower surface of the ice (1-3). Heat

60 advected into the EB interior by Atlantic water (AW) generally has not been considered

61 an important contributor to sea-ice reduction, due to effective insulation of the overlying

62 cold halocline layer (CHL) (4) that separates the cold and fresh SML and pack ice from

63 heat carried by the warm and saline AW.

64 There are, however, reasons to believe the role of AW heat in sea-ice reduction is not

65 negligible, and may be increasingly important (5). Nansen (6) identified the importance

66 of warm (temperature $>0{ }^{\circ} \mathrm{C}$ ) and salty intermediate-depth (150-900 m) AW in

67 establishing the thermal state of the Arctic Ocean. Later studies demonstrated that AW is

68 transported cyclonically (counter-clockwise) along the deep Arctic basin margins (7-10),

69 carrying enough heat, if released, to melt the Arctic sea ice many times over.

70 Observations from the 1990s and 2000s documented two warm, pulse-like AW

71 temperature anomalies on the order of $1{ }^{\circ} \mathrm{C}$ (relative to the 1970s), entering the Arctic

72 through Fram Strait and occupying large areas of the Arctic Ocean (11-14). The strength

73 of the 2000s warming peaked in 2007/08, with no analogy since the 1950s (14). This AW

74 warming has slowed slightly since 2008 (Fig. 2c).

75 Strong stratification, which is found in most of the Arctic Ocean, prevents vigorous

76 ventilation of the AW. One notable exception is the western Nansen Basin, north and 
77 northeast of Svalbard, where proximity to the sources of inflowing AW makes possible

78 significant interactions between the SML and the ocean interior (5). Specifically, weakly

79 stratified AW entering the Nansen Basin through Fram Strait is subject to direct

80 ventilation in winter, caused by cooling and haline convection associated with sea ice

81 formation (15). This ventilation leads to the reduction of sea-ice thickness along the

82 continental slope off Svalbard $(16,17)$. In the past, these conditions have been limited to

83 the western EB, since winter ventilation of AW in the eastern EB was constrained by

84 stronger stratification there. However, newly acquired data show that conditions

85 previously only identified in the western Nansen Basin now can be observed in the

86 eastern EB as well. We call this eastward progression of the western EB conditions the

87 "atlantification" of the EB of the Arctic Ocean.

\section{Overview of sea ice state}

89 The progressive decline in sea ice coverage of the Arctic Ocean during the satellite era, at

$90 \quad 13.4 \%$ per decade during September (18), has been accompanied by decreases in average

91 sea ice thickness of at least $1.7 \mathrm{~m}$ in the central Arctic $(19,20)$. In the region of the

92 eastern EB defined by the polygon in Fig. 1a, the local changes since 2003 have also been

93 substantial. With the northward retreat of multiyear sea ice cover (21), coverage within

94 that polygon is now dominated by seasonal ice, either advected from the east and south,

95 or produced locally. Mean September ice coverage has been $<10 \%$ of the total area

96 during the last five years, portending ice-free summers in coming years if current sea ice

97 trends prevail. Annual open water coverage has increased from less than one month to

98 more than three months in recent years (Fig. 1b); these longer ice-free periods,

99 maintained by atmospheric and ocean conditions, increase direct air-ocean interactions 
100 (momentum and energy exchanges). Available satellite estimates of ice thickness in this

101 region - typically sparse — suggest a concurrent trend, leading to an overall thinning of

$102 \sim 0.5 \mathrm{~m}$ (in March) from 2003 through 2015 (Fig. 1c). Satellite records show that this

103 pattern continued in 2016, with less extensive (compared with record minimum)

104 December sea-ice extent in the Kara and Barents Seas (22).

105 Role of atmospheric thermodynamics in sea-ice decline

106 Arctic-wide warming is evident from surface air temperature trends ranging between 0.1

107 and $0.3{ }^{\circ} \mathrm{C}$ per decade for the period 1984-2012 (23). Surface air temperature trends from

108 weather stations and ERA-Interim reanalysis data for the Laptev Sea and eastern EB

109 region far exceed observed average Arctic regional trends (Fig. S1a-c), consistent with

110 recently enhanced sea-ice decline. The net atmospheric thermodynamic impact on sea ice

111 cannot be quantified using surface air temperature records alone, as changes in this

112 parameter omit thermodynamic forcing due to additional atmospheric processes.

113 Fortunately, records are available for fast-ice (motionless seasonal sea ice anchored to

114 the shore, which melts and re-freezes each year) thickness, providing a measure of nearly

115 pure atmospheric thermodynamic forcing over the broad, shallow Siberian shelves, where

116 the impact of advected or seasonally stored oceanic heat is negligible. Records from five

117 locations along the Laptev Sea coast (Fig. S1e) have been used to construct a composite

118 time series showing that increased melting in the eastern EB/Laptev Sea region during

119 the last decade accounted for $\sim 18 \mathrm{~cm}$ of ice thickness loss (Fig. S1d). This estimate is

120 statistically significant (using the Student $t$ test), and suggests that atmospheric

121 thermodynamic forcing plays an important role in reducing EB sea-ice coverage. 
123 Observations from 2013 to 2015 using oceanographic moorings (Fig. S2) and drifting

124 Ice-Tethered Profiler buoys (ITPs) $(3,24)$ provide evidence that the eastern EB is in a

125 transition to conditions similar to the western Nansen Basin. Mooring observations over

126 the central Laptev Sea slope sustained since 2002 reveal anomalously strong seasonal

127 signals in the subsurface layers during recent years (Figs. 2c and S3). In particular, the

128 enhanced seasonal signals in the winters of 2013/14 and 2014/15 are associated with

129 warming (Fig. 2b, c) and shoaling of the AW layer (Fig. 2b, d), and weakening of the

130 stability of the CHL and upper pycnocline ( $\sim 50-150 \mathrm{~m}$, Fig. $2 \mathrm{~b})$. As a result, the strength

131 of the seasonal signal, as shown by wavelet analyses (Figs. 2d and S3), was intensified.

132 The AW layer's seasonal temperature range at the $\mathrm{M} 1_{4}$ mooring site increased from 0.2-

$133 \quad 0.3{ }^{\circ} \mathrm{C}$ in $2004 / 07$ (25) to over $1{ }^{\circ} \mathrm{C}$ in $2013 / 15$ (Fig 2b). Shoaling of the AW upper

134 boundary was also substantial, rising from $140 \mathrm{~m}$ in 2003/04 to $100 \mathrm{~m}$ in winter 2014/15

135 and even to $85 \mathrm{~m}$ in winter 2013/14 (Fig. 2d), with direct consequences for winter

136 entrainment of AW in the upper ocean.

137 Observations from the widely distributed array of moorings and ITPs can be used to

138 place measurements from the $\mathrm{M1}_{4}$ mooring location in a basin-wide context (Fig. 3).

139 Temperature and salinity distributions provided by ITP-93, which drifted along the

140 Lomonosov Ridge separating the Amerasian and Eurasian basins, are distinct from those

141 provided by other instruments (Fig. 3). They show a stable SML and CHL (white and

142 black lines in Fig. 3c; see Supplementary Materials for SML and CHL depth definitions),

143 and lack strong depth variability throughout the record. The ITP-93 record shows high

144 values for Brunt-Väisälä frequency (a measure of water column stability) at roughly 25- 
$14550 \mathrm{~m}$ depth from the beginning (September 22, 2015) to the end (April 22, 2016) of the

146 record, thus providing further evidence for minimal mixing along the eastern flank of the

147 EB in recent years (Fig. 3c).

148 ITP-57 drifted within the central Amundsen Basin in 2013. Its record shows, in

149 contrast, clear signs of winter ventilation associated with gradual cooling and erosion of

150 the CHL from November/December through April, weakening stratification at the base of

151 the SML, and a decrease in Brunt-Väisälä frequency in the CHL during March-April of

1522013 (Fig. 3d). Data from ITP-37 (not shown), which drifted in the same region in

$1532009 / 10$, indicated that the transfer of heat from the upper pycnocline $(\sim 65-100 \mathrm{~m})$ to the

154 SML is highest in winter, with an average heat loss of 3-4 $\mathrm{W} \mathrm{m}^{-2}$ between January and

155 April (14). This analysis has also suggested the increased heat transfer from the AW to

156 the SML in winter is likely caused by a combination of brine-driven convection,

157 associated with sea-ice formation and larger vertical velocity shear below the base of the

158 SML, which is enhanced by strong winter storms and a more mobile ice cover.

159 A year-long 2013/14 ITP-74 record from the central Nansen Basin showed deepening

160 of the SML to $\sim 130 \mathrm{~m}$ and disappearance of the CHL driven by winter convection in

161 March-April 2014, when the buoy was passing westward to the north of Franz Josef Land

162 (Fig. 3b). A seasonally ventilated halocline was also found in this region during a Russian

163 ice drift station NP-35 in 2007/08 (5) and in earlier observations $(26,27)$. The

164 disappearance of the CHL was also observed in the central Amundsen Basin in the mid-

165 1990s (28). This was explained by a deficit of freshwater in the region, due to a diversion

166 of Siberian river waters further eastward along the coast that was driven by changes in

167 the atmospheric circulation. 
168 The deep winter ventilation and the disappearance of the CHL in the eastern EB

169 (eastward from Severnaya Zemlya, $>90^{\circ} \mathrm{E}$ ) at several mooring sites in $2013-15$, however,

170 are unprecedented (Figs. 3a, 4). Significant changes in seasonal heat content $Q$ (see

171 definition in Supplementary Materials), driven by surface cooling and salinification

172 during winter sea-ice formation, occurred in the upper 130 -m layer at $\mathrm{M} 3 \mathrm{e}, \mathrm{M} 1_{3}, \mathrm{M} 1_{6}$,

173 and M6b mooring sites. If this trend persists, convectively-driven winter development of

174 the deep (>80 m) SML, combined with ventilation of the upper 130-m ocean and

175 associated disappearance of the CHL would represent a fundamental change, with the

176 eastern EB water column structure becoming less stratified and susceptible to further

177 mixing.

178 Role of oceanic heat in sea-ice decline

179 Figure 4 addresses the consequences of these changes for upward AW heat transfer.

180 Seasonal (winter-to-summer) cooling in the CHL and upper pycnocline $(65-130 \mathrm{~m}$, see

181 definition in Supplementary Materials) is quantified using linear trends in $Q$. These

182 trends $\left(\mathrm{Wm}^{-2}\right)$ characterize the rate of change in $Q$, and are equivalent to a divergent heat

183 flux $F_{h}$ (see definition in Supplementary Materials). Note that AW is the major source of

184 heat for the layer underlying the CHL in this part of the Arctic Ocean. The seasonal mean

$185 F_{h}$ through the CHL and upper pycnocline inferred from these trends varies from 3.3 to

$18624.1 \mathrm{Wm}^{-2}$ (Table 1; for reference, $1 \mathrm{Wm}^{-2}$ over a single year is equivalent to $\sim 10 \mathrm{~cm}$ of

187 ice loss).

188 Another potential contributor to the observed change in $Q$ may be the lateral advection

189 of heat. We argue, however, that the in-phase seasonal maxima and minima of wavelet

190 transforms of $Q$ as provided by all moorings (Fig. S4), and the lack of any lag between $Q$ 
191 calculated within separate overlying depth layers (not shown), each strongly suggest the

192 observed winter ventilation of the CHL and upper pycnocline is driven by surface cooling

193 and sea-ice formation — and not by lateral advection. Additional support for this statement

194 comes from the wavelet analysis of $Q$ records — not just from moorings $\mathrm{M}_{3}$ and $\mathrm{M} 1_{6}$, but

195 from all six moorings deployed across the EB continental slope during 2013/15 (see

196 Supplementary Materials for data description) — showing in-phase seasonal variations

197 (not shown). The very different speeds of water transports across the slope, ranging from

$19813 \mathrm{~cm} / \mathrm{s}$ (measured by $250-700 \mathrm{~m}$ shallow moorings) to $1-2 \mathrm{~cm} / \mathrm{s}$ (measured at $2700 \mathrm{~m}$

199 and deeper mooring locations) make the in-phase pattern of the seasonal signal at all

200 moorings impossible to explain using the advective mechanism. Moreover, the $\mathrm{M}_{6}$

201 mooring was placed in the ocean interior, well away from intense heat transports

202 associated with the near-slope boundary current, and yet data from this mooring yielded

203 estimates for $F_{h}$ consistent with estimates from other moorings deployed on the eastern

204 EB continental slope.

205 Spatial averaging yields a seasonal mean $F_{h}=12.2 \pm 3.8 \mathrm{~W} \mathrm{~m}^{-2}$ for winter $2013 / 14$ and

$2067.5 \pm 0.8 \mathrm{Wm}^{-2}$ for winter 2014/15 (Fig. 4 and Table 1). These inferred $F_{h}$ values exceed

207 previous estimates for upward heat fluxes of $O[3-4] \mathrm{Wm}^{-2}$, derived from 2007/08

208 microstructure observations over the Laptev Sea slope (33) and 2009/10 ITP-37

209 observations in the central Amundsen Basin (14) (Table 1), with new estimates for the

210 same region being 2-4 times higher. We thus argue that AW shoaling, weakening of

211 stratification, and warming of the upper pycnocline have led to seasonal upward AW heat

212 fluxes never before observed in the eastern EB.

213 The inferred heat fluxes are equivalent to 54 and $40 \mathrm{~cm}$ reductions in ice growth over 
214 the 2013/14 and 2014/15 winter seasons, respectively, in the eastern EB (time intervals

215 for seasons as defined by wavelet analysis, Fig. S4). The 2-4 fold increase in $F_{h}$ since

$2162007 / 08$ explains up to $18-40 \mathrm{~cm}$ of sea-ice loss due solely to an increase in upward AW

217 heat transport. These estimates are comparable to or even exceed $\sim 18 \mathrm{~cm}$ in sea-ice loss

218 attributed to atmospheric thermodynamic forcing, and partially explain eastern EB sea-

219 ice loss in recent years.

220 Sources of $\mathbb{E B}$ warm-water anomalies

221 Divergence of the Ekman transport (called Ekman pumping, see definition in

222 Supplementary Materials) may be a local factor, which can cause shoaling of AW and its

223 ventilation. However, our estimates suggest that Ekman pumping can explain only a

$2241.5 \mathrm{~m}$ seasonal shoaling of the AW, and therefore does not contribute substantially to the

225 anomalous state of the eastern EB in recent years (Fig. S5).

226 Geochemical observations demonstrated that fresh shelf waters cross the Laptev Sea

227 shelf break primarily at the Lomonosov Ridge-continental slope junction (35). Thus,

228 while variations in atmospheric forcing have been shown to affect the storage or release

229 of shelf waters (35) that impact stratification in the Amundsen Basin (28), such variations

230 likely play only a minor role in the recent changes observed in the eastern EB.

231 We thus conclude that the source of changes associated with the AW in the eastern EB

232 lies in processes beginning in upstream locations - namely, in Fram Strait and the

233 western EB north of Svalbard. Similar to eastern EB observations, the vertical

234 temperature difference in the upper ocean $(>250 \mathrm{~m})$ has been reduced in the area

235 northeast of Svalbard since 2004 (Fig. S6d, e) due to warming in the upper part of the

236 water column, mostly during winter. This trend is not present in data from Fram Strait, 
237 where the temperatures at both 75 and $250 \mathrm{~m}$ have changed very little (Fig. S6b, c).

238 One important difference between the eastern Fram Strait and the area northeast of

239 Svalbard is that the eastern (inflow) side of Fram has been essentially ice-free year-round

240 throughout recent history, while the slope north of Svalbard—beyond the Yermak

241 Plateau —has traditionally been ice-covered most of the year. In recent decades, larger

242 areas north of Svalbard have been ice-free for longer periods, primarily due to a

243 contemporary increase in temperature of the $\mathrm{AW}$ inflow $(16,17)$, similar to the response

244 in the Barents Sea to increased AW heat input there (36). During these extended ice-free

245 periods over the slope north of Svalbard, enhanced local wind-driven generation and

246 breaking of internal waves would be expected, as has been observed elsewhere in the

247 Arctic (37). As a result, increased sub-surface vertical mixing would tend to reduce the

248 temperature gradient, and increase $Q$ above the temperature maximum in the AW inflow

249 core — consistent with Fig. S6d, e. Additionally, the longer ice-free season over a larger

250 area allows more solar radiation to be absorbed in the upper ocean, thus compensating to

251 some degree for the increased local heat loss to the ice and atmosphere.

252 Discussion

253 This study provides evidence that the eastern EB is now in transition to conditions

254 previously unique to the western Nansen Basin — an extension of over $1500 \mathrm{~km}$ along the

255 AW pathway from Fram Strait, as far as $125^{\circ} \mathrm{E}$. The term 'atlantification' is applied to

256 the northward movement of sea ice in the Barents Sea, with attendant reductions in

257 stratification, increased vertical mixing, and altered primary production $(38,39)$. The

258 recent extension of "atlantification" far into the EB, and the suite of associated processes,

259 is shown conceptually in Fig. 5. The major driver for these changes is a powerful 
260 combination of processes associated with declining sea-ice cover and weakening of

261 stratification in the layers over AW. Gradual weakening of stratification in the eastern EB

262 halocline began in at least the 1970 s $(28,40)$, providing the necessary pre-conditioning

263 for a reconstruction of water mass structure. Weaker stratification and shoaling of the

$264 \mathrm{AW}$, together with net loss in ice volume, allow progressively deep winter ventilation in

265 the eastern EB. This ventilation has resulted in enhanced upward AW heat fluxes, key to

266 establishing the diminished sea-ice cover in the eastern EB during recent years.

267 Changes associated with "atlantification"-weakened stratification, increased vertical

268 mixing, and sea ice decline — will have dramatic impacts on other geophysical and

269 biogeochemical components of the Arctic Ocean system. These include enhanced

270 atmosphere-ocean interactions (with potential but highly debated mid-latitude

271 consequences; 41), altered freshwater storage and export patterns within the Arctic Ocean

272 (42), intensified shelf-basin exchange (43), increased primary production due to increased

273 nutrient supply (44), and possibly changing the ocean's response to acidification due to

274 the high buffering capacity of AW (45). While specific physical mechanisms involved in

275 sea ice decline and upper ocean ventilation remain under debate (5), it is likely that

276 higher-than-normal AW temperatures and salinities in the Nordic Seas, upstream of the

277 Arctic Ocean gateways (46), will promote the further eastward "atlantification" of the

278 polar basins. This follows with scenarios for regional ocean state responses to the climate

279 changes proposed in (47), and has significant effects for future changes in the Arctic

280 Ocean and its sea-ice cover. The validity of extrapolating trends in the Arctic climate

281 system into the future is impacted, however, by the existence of large-amplitude, high-

282 latitude variability (48-50). It is therefore imperative to apprehend how to separate 
283 climate trends and variability and to understand their nature, in order to improve accuracy

284 of climate projections.

285 
287 1. D. K. Perovich et al. Ann Glaciol. 52, 355-359 (2011).

288 2. D. K. Perovich et al. Geophys. Res. Lett. 41, 2019-2025 (2014).

289 3. J. M. Toole et al. J. Geophys. Res. 115, C10018 (2010).

290 4. K. Aagaard, L. K., Coachman, E. C. Carmack, Deep-Sea Res. 28, 529-545 (1981).

291 5. E. C. Carmack et al. Bull. Amer. Meteor. Soc. 96(12), 2079-2105 (2015).

292 6. F. Nansen. Sci. Results. 9, 427 (1902).

293 7. K. Aagaard, Rapp. P.-V. Reun. Cons. Int. Explor. Mer. 188, 11-22 (1989).

294 8. B. Rudels, E. P., Jones, L. G. Anderson, G. Kattner, in The Polar Oceans and Their Role

295 in Shaping the Global Environment: The Nansen Centennial Volume, AGU

296 Geophysical Monograph vol. 85, American Geophysical Union, Washington DC, 1994, $297 \quad 33-46(1994)$.

298 9. Y. Aksenov et al. J. Geophys. Res. 116, C09017 (2011).

299 10. A. Pnyushkov et al. Deep-Sea Res. I. 101, 80-97 (2015).

300 11. D. A. Quadfasel, A. Sy, D. Wells, A. Tunik, Nature. 350, 385 (1991).

301 12. E. C. Carmack et al. Geophys. Res. Lett. 22, 1061-1064 (1995).

302 13. I. V. Polyakov et al. Geophys. Res. Lett. 32, L17605 (2005).

303 14. I. V. Polyakov et al. J. Phys. Oceanogr. 43, 2142-2155 (2013).

304 15. V. Ivanov et al. J. Phys. Oceanogr. 46, 1437-1456 (2016).

305 16. V. V. Ivanov et al. Advances in Meteorology. 2012. Article ID 201818. 11 pp. (2012).

306 17. I. H. Onarheim, L. H., Smedsrud, R., Ingvaldsen, F. Nilsen, Tellus. 66, 23933 (2014).

307 18. D. G. Vaughan et al., In: Climate Change 2013: Cambridge University Press, 
308 Cambridge, United Kingdom and New York, NY, USA, pp. 317-382 (2013).

309 19. R. Kwok, D. A. Rothrock, Geophys. Res. Lett. 36, L15501 (2009).

310 20. R. Kwok, G. F. Cunningham, Phil. Trans. R. Soc. A. 373, 20140157 (2015).

311 21. I. V. Polyakov, J. Walsh, R. Kwok, Bull. Amer. Meteor. Soc. 93(2), 145-151 (2012).

312 22. Sea Ice Prediction Network (SIPN). Post-Season Report,

313 https://www.arcus.org/sipn/sea-ice-outlook/2016/post-season\#two (2016).

314 23. C. Li, B. Stevens, J. Marotzke, Geophys. Res. Lett. 42, 8131-8139, (2015).

315 24. R. Krishfield, J. Toole, A. Proshutinsky, M.-L. Timmermans, J. Oceanic and Atmos.

$316 \quad$ Tech. 25, (2008).

317 25. I. A. Dmitrenko, et al. J. Geophys. Res. 114, C06010 (2009).

318 26. B. Rudels, L. G. Anderson, E. P. Jones, J. Geophys. Res. 101, 8807-8821 (1996).

319 27. B. Rudels, P. Jones, U. Schauer, P. Eriksson, Polar Research. 23(2), 181-208 (2004).

320 28. M. Steele, T. Boyd, J. Geophys. Res. - Oceans. 103(C5), 10419-10435 (1998).

321 29. L. Padman, T. M. Dillon, J. Geophys. Res. 96 (C3), 4769-4782 (1991).

322 30. M. G. McPhee, T. Kikuchi, J. H. Morison, T. P. Stanton, Geophys. Res. Lett. 30(24), $2274(2003)$.

324 31. A. Sirevaag, I. Fer, J. Phys. Oceanogr. 39, 3049-3069 (2009).

325 32. I. Fer, R. Skogseth, F. Geyer, J. Phys. Oceanogr. 40(7), 1613-1630 (2010).

326 33. Y.-D. Lenn, et al., Geophys. Res. Lett. 36, L05601 (2009).

327 34. I. Fer, Atmos. Ocean. Sci. Lett. 2, 148-152 (2009).

328 35. D. Bauch, D., I. A. Dmitrenko, C. Wegner, J. Hölemann, S. A. Kirillov, L. A.

329 Timokhov, H. Kassens. J. Geophys. Res., 114, C05008, 
doi:10.1029/2008JC005062, (2009).

331 36. M. Årthun, T. Eldevik, L- H. Smedsrud, Ø. Skagseth, R. B. Ingvaldsen, J. Clim., 25, $332 \quad 4736-4743(2012)$.

333 37. L. Rainville, R. A. Woodgate, Geophys. Res. Lett. 36, L23604 (2009).

334 38. M. Reigstad, P. Wassmann, C. W. Riser, S. Øygardena, F. Reyb, J. Marine Systems. 38, 335 9-29 (2004).

39. P. Wassmann, et al., In: The Organic Carbon Cycle in the Arctic Ocean. Springer337 Verlag Heidelberg-Berlin-New York, pp.101-138 (2004).

338 40. I. V. Polyakov, et al., J. Phys. Oceanogr. 40, 2743-2756 (2010).

339 41. J. Cohen et al., Nature Geoscience. 7, 627-637 (2014).

340 42. E. C. Carmack, et al., J. Geophys. Res. - Global Biogeochemical Cycles. 121, $675-$ $341 \quad$ 717, doi:10.1002/2015JG003140/full (2016).

342 43. W. Williams, C. E. Carmack, Progress in Oceanography. 343 http://dx.doi.org/10.1016/j.pocean.2015.07.008 (2015).

344 44. B. A. Bluhm, K. N. Kosobokoba, E. C. Carmack, Progress in Oceanography, 345 http://dx.doi.org/10.1016/j.pocean.2015.07.011 (2015).

346 45. M. Yamamoto-Kawai, F. McLaughlin, E. C. Carmack, J. Geophys. Res. - Oceans. $347 \quad 118(2013)$.

348 46. K. M. H. Larsen, C. Gonzalez-Pola, P. Fratantoni, A. Beszczynska-Möller, S. L. 349 Hughes, (Eds.) ICES Report on Ocean Climate 2015. ICES Cooperative Research $350 \quad$ Report. 331. 79 pp. (2016).

351 47. K. Aagaard, E. C. Carmack, In The Polar Oceans and Their Role in Shaping the 
Global Environment, Geophys. Monogr. Ser., vol. 85, edited by O. M. C., doi:10.1029/GM085p0005 (1994).

48. I. V. Polyakov, et al., Ecol. Applications. 23(8), 1745-1764 (2013).

49. A. Proshutinsky, D. Dukhovskoy, M.-L. Timmermans, R. Krishfield, J. L. Bamber, Phil. Trans. A. 373: 20140160. http://dx.doi.org/10.1098/rsta.2014.0160 (2015).

358 50. R. Zhang, PNAS, 112, 4570-4575 (2016).

359 51. V. V. Ivanov et al., Deep-Sea Res. I. 56, 1-14 (2009).

360 52. Polyakov, I. V. NSF Arctic Data Center. arctic-data.7792.16 (2016).

361 53. C. Torrence, G. P. Compo, Bull. Amer. Meteor. Soc. 79(1), 61-78 (1998).

362 54. G. Monterey, S. Levitus, S. NOAA Atlas NESDIS 14, U.S. Gov. Printing Office, 363 Wash., D.C., 96 pp (1997).

364 55. P. Bourgain, J.-C. Gascard, Deep-Sea Res. I, 58, 745-756 (2011). 
373 Acknowledgments. This study was supported by NSF grants \#1203473 and \#1249133

374 (AP, IP, MA, RR, VI), NOAA grant \# NA15OAR4310155 (AP, IP, MA, RR, TB, VI)

375 and by the A-TWAIN project, funded by the Arctic Ocean program at the FRAM-High

376 North Research Centre for Climate and the Environment. We thank Henriksen SS for help

377 with logistics. The mooring recovery and deployment was a great team effort by all

378 onboard the R/V Akademik Fedorov (2013) and R/V Akademik Tryoshnikov (2015). We

379 thank our colleagues from the Arctic and Antarctic Research Institute, Russia,

380 particularly V. Vizitov, V. Zaitsev, and E. Morozova, for their help with cruise

381 preparations. All mooring data used in this study are available on the web at

382 https://arcticdata.io/catalog/\#view/arctic-data.7792.4 (Ref. 52).

383 Author Contributions. All authors participated in data processing and preliminary analysis;

384 AP, IA, IP, RR, and VI carried out statistical analysis of data, RK provided sea-ice

385 information and processing, TK processed Fram Strait data, AS provided processing and

386 analysis for Svalbard mooring data, AY analyzed fast ice thickness data, and TB worked

387 with reanalysis data. All authors contributed to interpreting the data and writing the paper.

388 Author Information. The authors declare no competing financial interests. Correspondence

389 and requests should be addressed to IP (igor@iarc.uaf.edu). 
396 Table 1: Estimates of upward heat fluxes $F_{h}\left(\mathrm{~W} / \mathrm{m}^{2}\right)$.

\begin{tabular}{|c|c|c|c|c|c|}
\hline Region & Topography & Depth level & $F_{h}$ & Method & Source \\
\hline \multicolumn{6}{|c|}{ Previous estimates, Eurasian Basin } \\
\hline Yermak Plateau & Steep & Halocline & 25 & $\begin{array}{l}\text { Microstructure } \\
\text { profiles }\end{array}$ & Ref. 29 \\
\hline Yermak Plateau & Steep & Ice-ocean interface & 22 & $\begin{array}{l}\text { Turbulent flux } \\
\text { buoy }\end{array}$ & Ref. 30 \\
\hline $\begin{array}{l}\text { North of } \\
\text { Svalbard }\end{array}$ & Steep & $\begin{array}{l}\text { Ice-ocean interface } \\
\text { Halocline }\end{array}$ & $\begin{array}{l}O[100] \\
O[100]\end{array}$ & $\begin{array}{l}\text { Eddy covariance, } \\
\text { Microstructure } \\
\text { profiles }\end{array}$ & Ref. 31 \\
\hline $\begin{array}{l}\text { North of } \\
\text { Svalbard }\end{array}$ & Slope & Halocline & $2-4$ & $\begin{array}{l}\text { Microstructure } \\
\text { profiles }\end{array}$ & Ref. 32 \\
\hline Laptev Sea & Slope & $\begin{array}{l}\text { Above AW core } \\
(>250 \mathrm{~m})\end{array}$ & 3 & $\begin{array}{l}\text { Microstructure } \\
\text { profiles }\end{array}$ & Ref. 33 \\
\hline $\begin{array}{l}\text { Amundsen } \\
\text { Basin }\end{array}$ & Interior & $\begin{array}{l}\text { Upper CHL } \\
\text { SML }\end{array}$ & $\begin{array}{l}0.05 \\
0.2\end{array}$ & $\begin{array}{l}\text { Microstructure } \\
\text { profiles }\end{array}$ & Ref. 34 \\
\hline $\begin{array}{l}\text { Amundsen } \\
\text { Basin }\end{array}$ & Interior & $\begin{array}{l}\text { Between SML and } \\
\text { AW core }\end{array}$ & $3-4$ & $\begin{array}{l}\text { ITP, heat content } \\
\text { difference }\end{array}$ & Ref. 14 \\
\hline \multicolumn{6}{|c|}{ Estimates from this study, eastern Eurasian Basin } \\
\hline $\begin{array}{l}\text { Eastern EB, off } \\
\text { Severnaya } \\
\text { Zemlya }\end{array}$ & Steep slope & $\begin{array}{l}\text { Between SML and } \\
\text { AW core }\end{array}$ & $5.0-10.3$ & $\begin{array}{l}\text { Heat content } \\
\text { difference }\end{array}$ & M6b mooring \\
\hline $\begin{array}{l}\text { Eastern EB, } \\
\text { central Laptev } \\
\text { Sea, 125E }\end{array}$ & Slope & $\begin{array}{l}\text { Between SML and } \\
\text { AW core }\end{array}$ & $8.4-24.1$ & $\begin{array}{l}\text { Heat content } \\
\text { difference }\end{array}$ & $\mathrm{M}_{3}$ mooring \\
\hline $\begin{array}{l}\text { Eastern EB, } \\
125 \mathrm{E}\end{array}$ & Interior & $\begin{array}{l}\text { Between SML and } \\
\text { AW core }\end{array}$ & $6.9-11.2$ & $\begin{array}{l}\text { Heat content } \\
\text { difference }\end{array}$ & $\mathrm{M1}_{6}$ mooring \\
\hline $\begin{array}{l}\text { Eastern EB, off } \\
\text { Novosibirskiye } \\
\text { Islands }\end{array}$ & Slope & $\begin{array}{l}\text { Between SML and } \\
\text { AW core }\end{array}$ & $3.3-9.5$ & $\begin{array}{l}\text { Heat content } \\
\text { difference }\end{array}$ & M3e mooring \\
\hline
\end{tabular}


$400 \quad$ Figure 1: Sea ice fraction and thickness in the eastern Eurasian Basin (EB) since 2003.

401 Sampling of the sea ice state within the region (of $0.41 \times 10^{6} \mathrm{~km}^{2}$, defined in (a)) shows a

402 positive trend in annual open water coverage (in months, integrated over a seasonal cycle,

403 (b)), this is accompanied by decreases in mean March ice thickness and monthly mean

404 sea ice coverage in (c) (measured as fraction of the total area). For the past five summers

405 (2011 thru 2015), the mean September ice coverage has been less than $10 \%$ ice coverage, 406 and seems to be approaching a seasonally ice-free state. Dashed box (in blue) shows the 407 geographic coverage of the map in Fig. 2a, within the Arctic basin. Red dashed line in (a)

408 identifying the Lomonosov Ridge separates the Amerasian and Eurasian basins.

409 Figure 2: Mooring locations and time series and their wavelet transforms from the 410 mooring site $\mathrm{M1}_{4}$, eastern EB of the Arctic Ocean. (A) Map showing locations of 411 oceanographic moorings. The Gakkel Ridge (GR) divides the EB into the Nansen Basin 412 (NB) and the Amundsen Basin (AB). The Lomonosov Ridge (LR), Novosibirskiye Islands 413 (NI), Severnaya Zemlya (SZ), Franz Joseph Land (FJL), and Makarov Basin (MB) are 414 indicated. Dotted lines show latitudes and longitudes; grey solid lines show depth in 415 meters. (B) Vertical profiles show increasing water temperature $\left({ }^{\circ} \mathrm{C}\right)$ and salinity and 416 decreasing stability expressed as the logarithm of squared Brunt-Väisälä frequency $\left(\mathrm{N}^{2}, \mathrm{~s}^{-2}\right.$, 417 a measure of water column stability) within the Cold Halocline Layer (CHL) and upper 418 pycnocline ( $40-150 \mathrm{~m})$ in the 2000 s and early 2010s. (C) Composite time series of water 419 temperature (dotted lines for daily, solid lines for monthly means). White segments 420 indicate missing data. (D) Original (light blue) and de-trended (dark blue) time series of 421 the upper Atlantic Water (AW) boundary (defined by $0{ }^{\circ} \mathrm{C}$ isotherm, left) and wavelet 422 transforms of de-trended time series (right). In panels with wavelet transforms, $95 \%$ 423 statistical significance and cones of influence are shown by grey lines.

424 Figure 3: (top) Potential temperature $\left({ }^{\circ} \mathrm{C}\right)$, (middle) salinity, and (bottom) logarithm of $425 \mathrm{~N}^{2}\left(\mathrm{~s}^{-2}\right)$ from (a) mooring and (b-d) along the Ice Tethered Profiler drifts. White segments 426 indicate missing data. White solid lines show the depth of the surface mixed layer (SML) 427 and black solid lines show the depth of the underlying cold halocline layer (CHL) base; 428 disappearance of the black line signifies disappearance of $\mathrm{CHL}$ and ventilation of the 
upper ocean.

$430 \quad$ Figure 4: (left) Depth (m)-time distributions of temperature, $T$, and (right) time series of

431 heat content, $Q$, (dotted blue lines = daily, solid blue lines = monthly means, and green

432 dashed line = standard errors) for the 65-130 m layer (see mooring locations in Fig. 2).

433 Maxima and minima of wavelet transforms were used to define the boundary of winter

434 seasons (Fig. S4). These boundaries were used to calculate trends in $Q$ shown by red

435 (winter 2013/14) and orange (winter 2014/15) lines. Slope of trends defines the rate of

436 change of $Q$ in time, which is equivalent to the divergent heat flux $F_{h}$ (shown in red and

437 orange).

438 Figure 5: Conceptual model of "atlantification" of the eastern EB continental margin in

439 recent years. The broad arrow extending from the right hand side shows the

440 encroachment of a suite of processes associated with atlantification; these are (1)

441 increased penetration of surface signature of AW (increased flow, heat content or both)

442 into the eastern EB, (2) reduction in ice cover resulting in (3) greater surface heat and

443 moisture flux and (4) increased depth of winter penetrative convection, bringing

444 additional heat and nutrients from AW into the Arctic Surface water and transformation

445 of the permanent cold halocline layer (CHL) to a seasonal halocline. SML and UPP

446 indicate the surface mixed layer and upper permanent pycnocline. WC shows winter

447 convection; red arrows indicate upward heat fluxes. Horizontal red arrows show inflows. 
a)

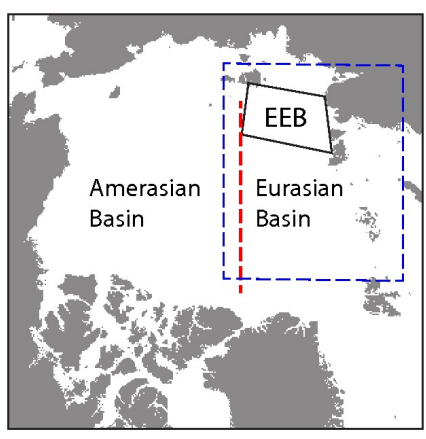

b)

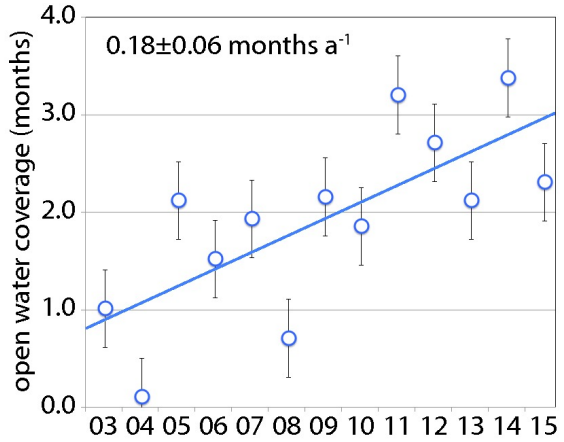

Year

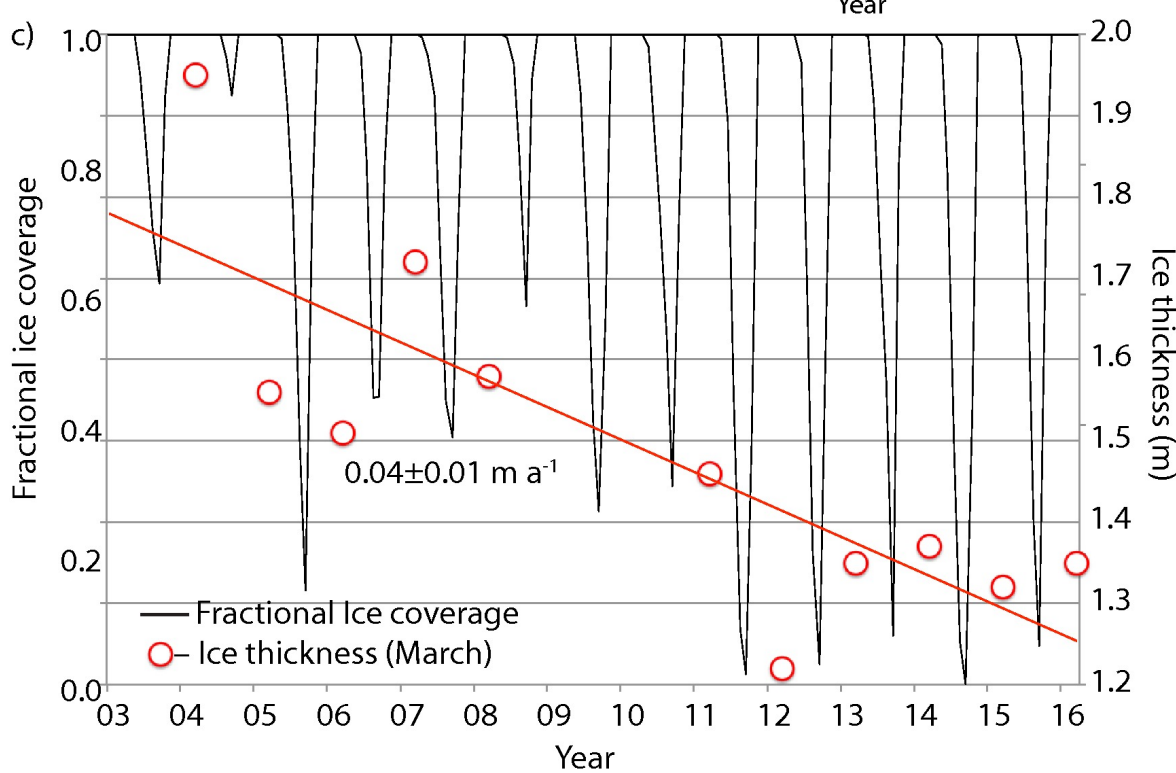

451 Figure 1: Sea ice fraction and thickness in the eastern Eurasian Basin (EB) since 2003.

452 Sampling of the sea ice state within the region (of $0.41 \times 10^{6} \mathrm{~km}^{2}$, defined in (a)) shows a

453 positive trend in annual open water coverage (in months, integrated over a seasonal cycle,

454 (b)), this is accompanied by decreases in mean March ice thickness and monthly mean

455 sea ice coverage in (c) (measured as fraction of the total area). For the past five summers

456 (2011 thru 2015), the mean September ice coverage has been less than $10 \%$ ice coverage,

457 and seems to be approaching a seasonally ice-free state. Dashed box (in blue) shows the

458 geographic coverage of the map in Fig. 2a, within the Arctic basin. Red dashed line in (a)

459 identifying the Lomonosov Ridge separates the Amerasian and Eurasian basins. 
A. Map with mooring locations

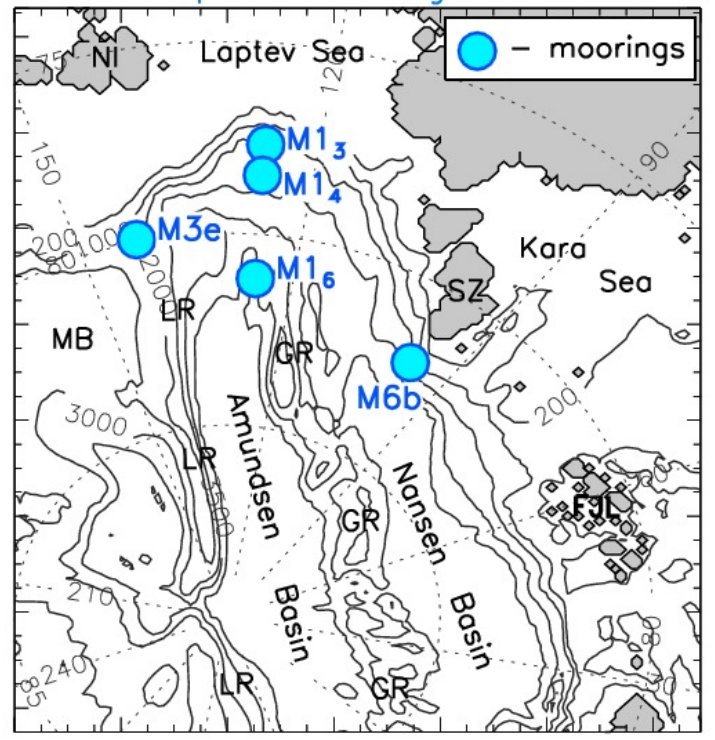

B. CTD profiles

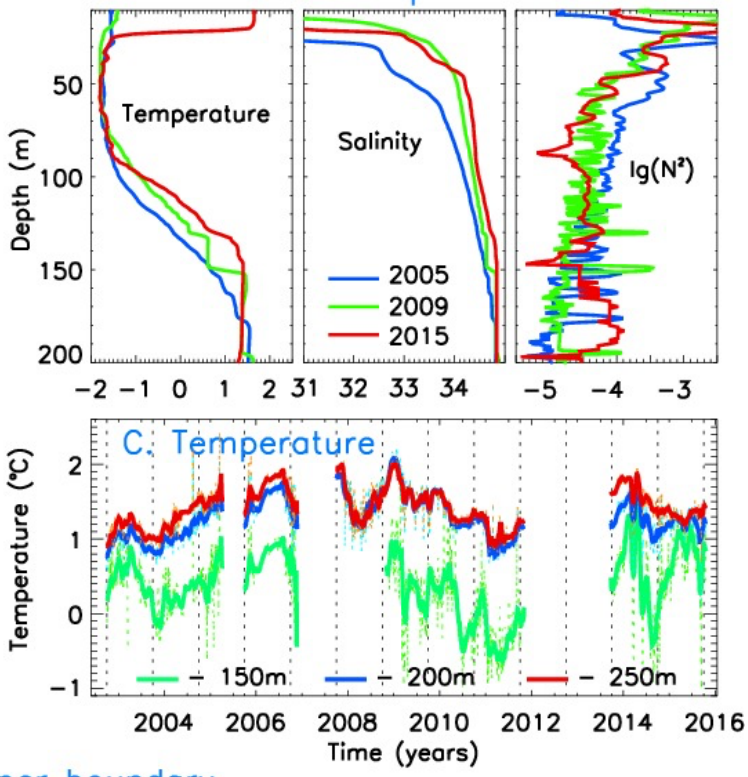

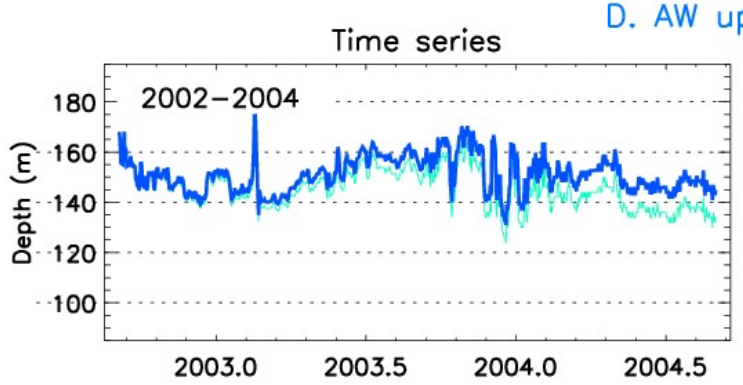
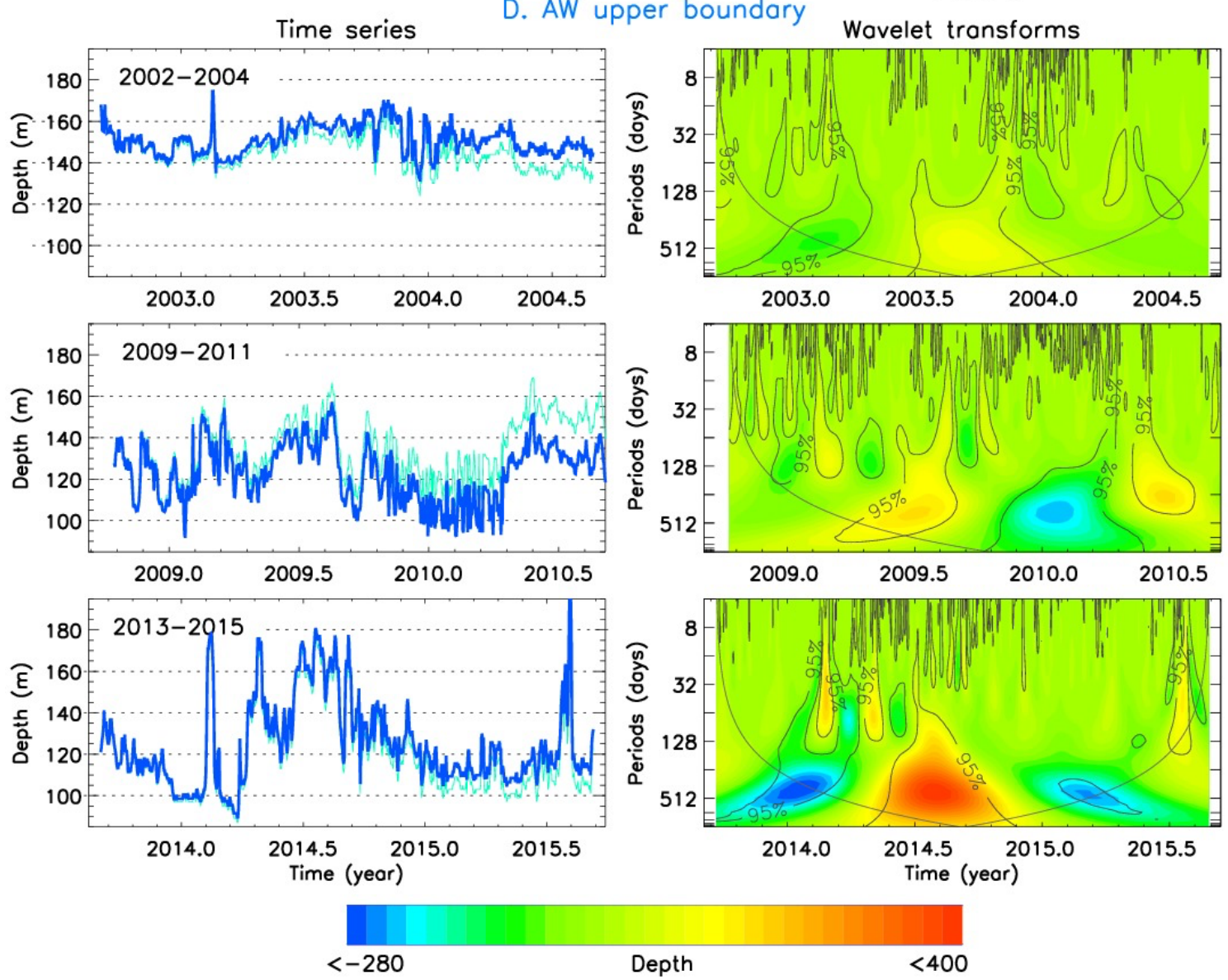

461 Figure 2: Mooring locations and time series and their wavelet transforms from the

462 mooring site $\mathrm{M1}_{4}$, eastern EB of the Arctic Ocean. (A) Map showing locations of

463 oceanographic moorings. The Gakkel Ridge (GR) divides the EB into the Nansen Basin 
464 (NB) and the Amundsen Basin (AB). The Lomonosov Ridge (LR), Novosibirskiye Islands 465 (NI), Severnaya Zemlya (SZ), Franz Joseph Land (FJL), and Makarov Basin (MB) are 466 indicated. Dotted lines show latitudes and longitudes; grey solid lines show depth in 467 meters. (B) Vertical profiles show increasing water temperature $\left({ }^{\circ} \mathrm{C}\right)$ and salinity and 468 decreasing stability expressed as the logarithm of squared Brunt-Väisälä frequency $\left(\mathrm{N}^{2}, \mathrm{~s}^{-2}\right.$, 469 a measure of water column stability) within the Cold Halocline Layer (CHL) and upper 470 pycnocline ( $\sim 40-150 \mathrm{~m}$ ) in the 2000s and early 2010s. (C) Composite time series of water 471 temperature (dotted lines for daily, solid lines for monthly means). White segments 472 indicate missing data. (D) Original (light blue) and de-trended (dark blue) time series of 473 the upper Atlantic Water (AW) boundary (defined by $0{ }^{\circ} \mathrm{C}$ isotherm, left) and wavelet 474 transforms of de-trended time series (right). In panels with wavelet transforms, $95 \%$ 475 statistical significance and cones of influence are shown by grey lines.

476 


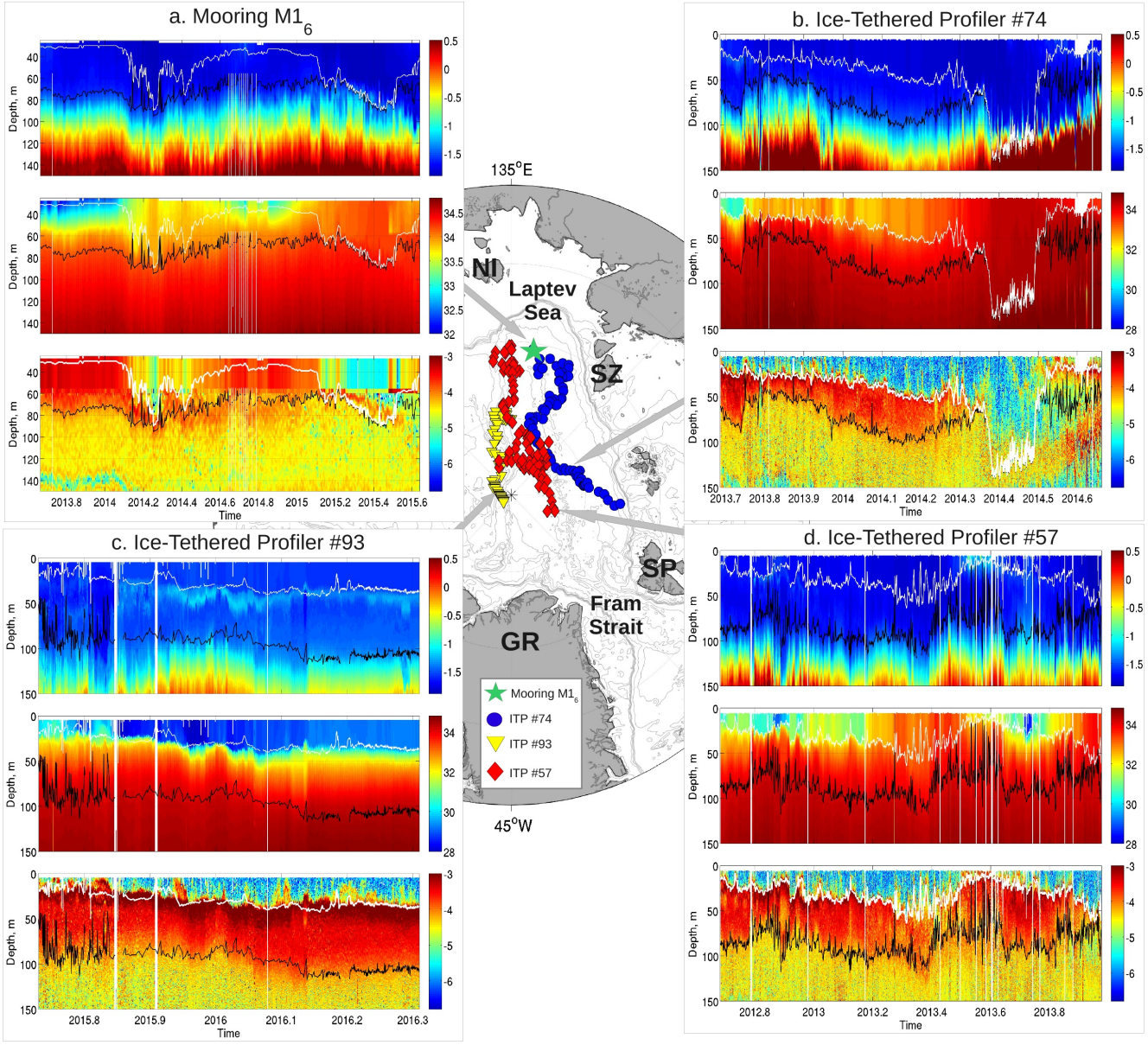

478 Figure 3: (top) Potential temperature $\left({ }^{\circ} \mathrm{C}\right)$, (middle) salinity, and (bottom) logarithm of

$479 \mathrm{~N}^{2}\left(\mathrm{~s}^{-2}\right)$ from (a) mooring and (b-d) along the Ice Tethered Profiler drifts. White segments

480 indicate missing data. White solid lines show the depth of the surface mixed layer (SML)

481 and black solid lines show the depth of the underlying cold halocline layer (CHL) base;

482 disappearance of the black line signifies disappearance of CHL and ventilation of the 483 upper ocean. 


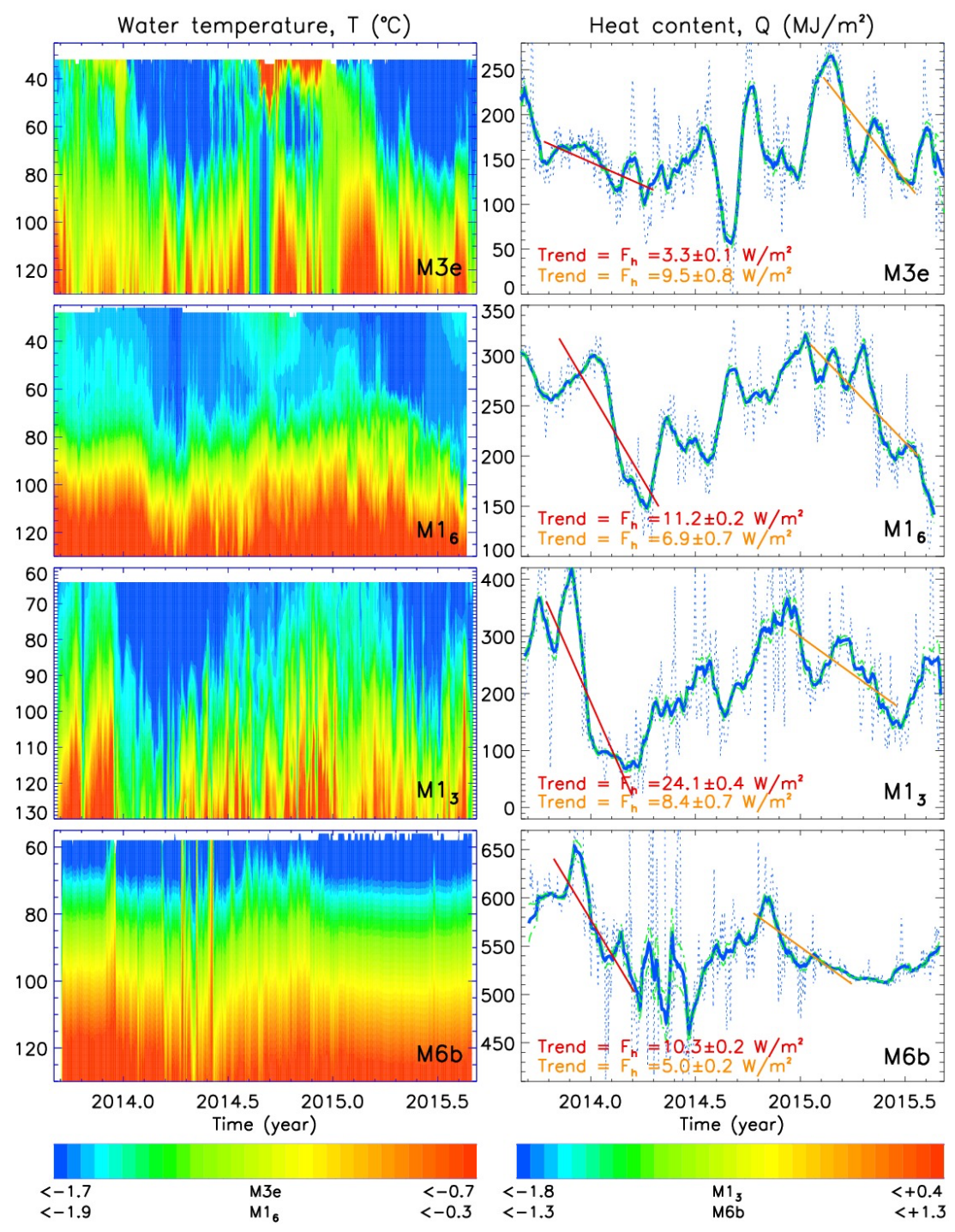

485 Figure 4: (left) Depth (m)-time distributions of temperature, $T$, and (right) time series of 486 heat content, $Q$, (dotted blue lines = daily, solid blue lines = monthly means, and green 487 dashed line $=$ standard errors) for the 65-130 m layer (see mooring locations in Fig. 2). 488 Maxima and minima of wavelet transforms were used to define the boundary of winter 489 seasons (Fig. S4). These boundaries were used to calculate trends in $Q$ shown by red 490 (winter 2013/14) and orange (winter 2014/15) lines. Slope of trends defines the rate of 491 change of $Q$ in time, which is equivalent to the divergent heat flux $F_{h}$ (shown in red and 492 orange). 


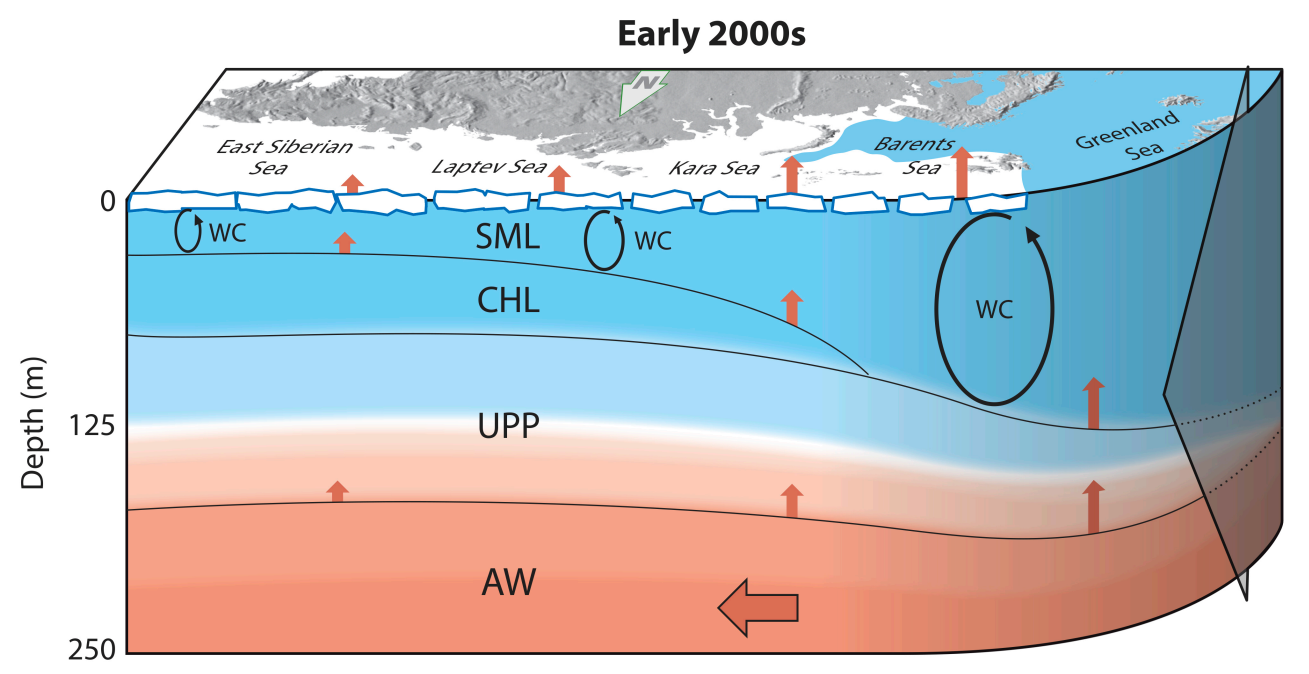

Mid-2010s

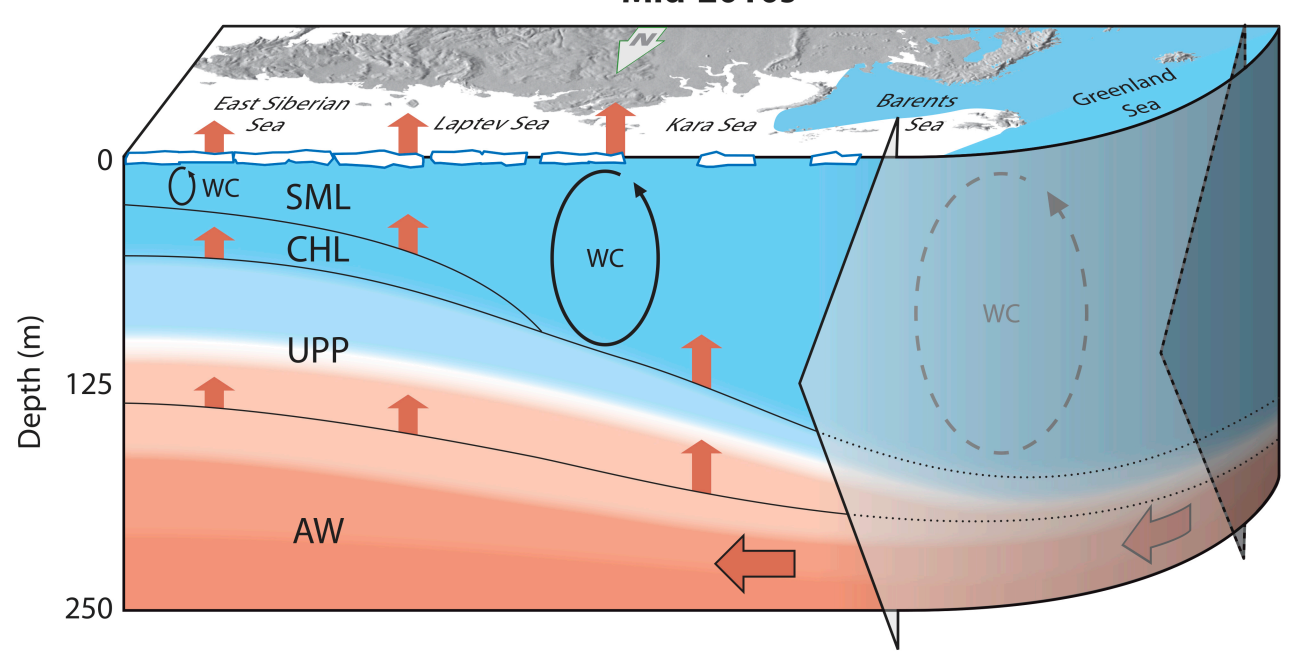

494 Figure 5: Conceptual model of "atlantification" of the eastern EB continental margin in 495 recent years. The broad arrow extending from the right hand side shows the encroachment 496 of a suite of processes associated with atlantification; these are (1) increased penetration of 497 surface signature of AW (increased flow, heat content or both) into the eastern EB, (2) 498 reduction in ice cover resulting in (3) greater surface heat and moisture flux and (4) 499 increased depth of winter penetrative convection, bringing additional heat and nutrients 500 from AW into the Arctic Surface water and transformation of the permanent cold halocline 501 layer (CHL) to a seasonal halocline. SML and UPP indicate the surface mixed layer and 502 upper permanent pycnocline. WC shows winter convection; red arrows indicate upward 503 heat fluxes. Horizontal red arrows show inflows. 


\section{Supplementary Materials for}

\section{Greater role for Atlantic inflows on sea-ice loss in the Eurasian Basin of the Arctic Ocean}

Igor V. Polyakov, Andrey V. Pnyushkov, Matthew B. Alkire, Igor M. Ashik, Till M. Baumann, Eddy C. Carmack, Ilona Goszczko, John Guthrie, Vladimir V. Ivanov, Torsten Kanzow, Richard Krishfield, Ronald Kwok, Arild Sundfjord, James Morison, Robert Rember, Alexander Yulin correspondence to: igor@iarc.uaf.edu

\section{This PDF file includes:}

Materials and Methods

Supplementary Text

Figs. S1 to S6

Table S1 


\section{Satellite Observations}

Ice concentration fields are those from AMSR. Gridded monthly fields of ICESat and CS-2 ice thickness estimates are those described in Ref. 20. The assessed differences between ICESat and various measurements are: $0.14 \pm 0.51 \mathrm{~m}$ (ice draft from moorings), and $-0.1 \pm 0.42 \mathrm{~m}$ (submarine ice draft). Differences between CS-2 and various measurements are: $0.06 \pm 0.29 \mathrm{~m}$ (ice draft from moorings), $0.07 \pm 0.44 \mathrm{~m}$ (submarine ice draft), $0.12 \pm 0.82 \mathrm{~m}$ (airborne electromagnetic profiles), and $-0.16 \pm 0.87 \mathrm{~m}$ (Operation IceBridge).

\section{Mooring Observations}

Our analysis utilizes the collection of instrumental observations of ocean temperature and salinity from five moorings distributed in the eastern EB (Fig. 2). Moorings provided CTD (Conductivity-Temperature-Depth) profiles from McLane Moored Profilers (MMP) (M1 3 and $\mathrm{M}_{6}$ moorings only) and SBE-37 CTD time series and SBE-56 temperature time series from fixed depth observations. Mooring schematics with depths of each SBE-37 instrument and depth ranges for MMPs are shown in Supplementary Materials Fig. S2.

The MMP temperature and conductivity calibrated measurement accuracies are $\pm 0.002^{\circ} \mathrm{C}$ and $\pm 0.002 \mathrm{mS} / \mathrm{cm}$, respectively. The MMP sampled a vertical profile along a mooring line once per day at a speed of $\sim 25 \mathrm{~cm} / \mathrm{s}$ with a sampling period of $0.5 \mathrm{~s}$; therefore, the data had a vertical spacing of $\sim 12 \mathrm{~cm}$. SBE-37 and SBE-56 provided $15-$ min interval records with measurement accuracies of $\pm 0.002^{\circ} \mathrm{C}$ and $\pm 0.003 \mathrm{mS} / \mathrm{cm}$ for SBE-37 temperature and conductivity and of $\pm 0.002^{\circ} \mathrm{C}$ for SBE-56 temperature. All eastern EB moorings were deployed in summer 2013 and recovered in summer 2015 providing full two-year long records for all instruments (with a few exceptions). Two single moorings (M3e and M6b) were located off Novosibirskiye Islands and Severnaya Zemlya. Six moorings formed a cross-slope section along approximately $126^{\circ} \mathrm{E}$ meridian. Only $\mathrm{M}_{3}, \mathrm{M}_{4}$, and $\mathrm{M}_{6}$ from this array, however, were used in this analysis. Despite thinning, the reduced dataset provides a robust description of seasonal variability relevant to the present study. Locations of moorings used in this study are shown in Fig. 2. In addition, at $\mathrm{M1}_{4}$ mooring site observations began in August 2002 thus providing invaluable long-term (with several gaps caused by malfunction of MMP and discontinuity of funding) measurements. Observations started some distance (32-65m depending on mooring) from the surface in order to avoid potential loss of the moorings being trapped and destroyed by ice keels. That limited our ability to define summer SML depths for all moorings. Mooring data used in this study are available on the web, at https://arcticdata.io/catalog/\#view/arctic-data.7792.4 (52).

In Fram Strait, we utilized long-term observations along the $78^{\circ} 50^{\prime} \mathrm{N}$ latitude, which extended from the eastern Greenland shelf break $\left(6^{\circ} 51^{\prime} \mathrm{W}\right)$ to the western shelf break off Svalbard $\left(8^{\circ} 40^{\prime} \mathrm{E}\right)$. We focused our analysis on observations at mooring F3 in the eastern part of this section. This mooring was deployed within the West Spitsbergen Current (WSC) carrying AW into the Arctic Ocean, in proximity to the origin of the Fram Strait branch of AW circulation in the EB. Here, we used observations collected during 19972015 with several periods with missing data. 
North of Svalbard $\left(81^{\circ} 30^{\prime} \mathrm{N}, 31^{\circ} 00^{\prime} \mathrm{E}\right)$, moorings covering the Fram Strait inflow branch of the WSC over the upper part of the continental slope have been maintained since 2004 (51). The core of the inner branch of the WSC extends over bottom depths of around 500-1500 $\mathrm{m}$ and the moorings used in the present study have been positioned over depths between 850 and $1180 \mathrm{~m}$. $\underline{\text { Ice }}$ Tethered Profiler $\underline{\text { Observations }}$

ITP buoys $(3,23)$ (www.whoi.edu/itp) provided twice-daily CTD profiles in the upper $\sim 750 \mathrm{~m}$ of the EB. The ITP CTDs were equipped with SBE-41/41CP CTD sensors and had high vertical resolution $\left(25 \mathrm{~cm}\right.$ or better) and accuracy of temperature $0.002^{\circ} \mathrm{C}$ and salinity 0.002 . Data processing procedures are described at: $\mathrm{http}: / / \mathrm{www}$.whoi.edu/fileserver.do?id=35803\&pt=2\&p=41486. In our analysis we used data interpolated to a $25 \mathrm{~cm}$ fixed vertical grid; i.e., close to the original sampling interval. The time intervals covered by buoy measurements are shown by horizontal axes in Fig. 3b-d.

\section{Fast-Ice Data}

Fast-ice thickness observations at polar stations are conducted in winter by direct measurements of ice thickness at the same locations each year through the hole in ice using a ruler. Maximum thickness reached by seasonal ice in each year was used in this study to compose local and regional time series.

\section{Atmospheric Data}

De-seasoned monthly $2 \mathrm{~m}$ air temperatures from the European Centre for MediumRange Weather Forecasts reanalysis ERA-Interim were used to complement stationbased monthly mean temperature records in the Laptev Sea region (stations Kotelnii and Cheluskin) and expand the analysis to the eastern EB (Supplementary Materials Fig. S1).

\section{Ekman Pumping}

Ekman pumping velocity, $w_{e}\left(\mathrm{~m} \mathrm{~s}^{-1}\right)$, is given by:

$$
w_{e}=\frac{1}{\rho_{o} f}[\nabla \times \tau]
$$

where $\tau$ is the surface wind stress, $\rho_{o}=1027 \mathrm{~kg} \mathrm{~m}^{-3}$ is the density of water, $f=2 \omega \sin \varphi$ is the Coriolis parameter, $\varphi$ is latitude. Time series of wind stress were derived from ERA Interim Reanalysis sea level pressure by calculating geostrophic wind speed $U$ (the area within $250 \mathrm{~km}$ of $84^{\circ} \mathrm{N}, 125^{\circ} \mathrm{E}$ ) and using the following empirical formula:

$$
\tau=\rho_{a} C_{D} U|U|
$$

where $C_{D}=1.2 \times 10^{-3}$ is empirical constant and $\rho_{a}=1.29 \mathrm{~kg} \mathrm{~m}^{-3}$ is air density. Positive (negative) values represent cyclonic (anticyclonic) wind stress exerted on the surface causing a confluence (diffluence) of surface waters resulting in upwelling (downwelling) processes. Calculations of $w_{e}$ were made without taking into account effects of ice. It has been shown that for the eastern EB, these effects are generally small; moreover, they tend to reduce the effect of wind (14).

\section{Wavelet Analysis} transformation of time series. Standard package of wavelet programs is used for 
calculation of wavelet transforms based on the DOG Mother function (53). 95\% confidence intervals and cones of influence shown in wavelet presentations are provided by the same package.

We identify the depth of the SML by a change in water density from the ocean surface of $0.125 \mathrm{~kg} / \mathrm{m}^{3}$, following Ref. 54 . The lower CHL boundary is defined following ref. 55 where an extensive collection of modern data was used and it was argued that the density ratio $R_{\rho}=(\alpha \partial \theta / \partial z) /(\beta \partial S / \partial z)=0.05$ ( $\alpha$ is the thermal expansion coefficient and $\beta$ is the haline contraction coefficient, $\theta$ is potential temperature and $S$ is salinity) may be used to establish the depth of the CHL base.

\section{Definition of Heat Content $Q$}

We quantify the changes in the CHL using vertically integrated heat content $Q$ $\left(\mathrm{J} / \mathrm{m}^{2}\right)$, defined as

$$
Q=\int_{z_{1}}^{z_{2}} \rho_{w} c_{p}\left(\theta-\theta_{\text {freezing }}\right) d z,
$$

where, $\theta_{\text {freezing }}$ is the freezing temperature (-0.054.S may serve as a good proxy for the freezing point temperature), $\rho_{\mathrm{w}}$ is water density, $c_{p}$ is specific heat of seawater and $z_{l}$ and $z_{2}$ are depths of the upper and lower boundaries. In physical terms, $Q$ may be interpreted as the relative heat content, measuring how much heat must be removed to form ice crystals at a particular salinity and pressure.

\section{Definition of Divergent $\underline{\text { Heat Flux }} \underline{F_{h}}$}

We describe divergence of vertical heat flux $F_{h}$ as the difference of diapycnal heat fluxes $F_{h}$ at two depth levels. $F_{h}$ is estimated from changes in time of vertically integrated heat content $\Delta Q$. Note that these values are flux differences, and total heat fluxes may be larger than these values due to additional non-divergent heat transports (thus, our inferred estimates of heat fluxes represent lower bound for the total heat flux). For details, see Ref. 14.

\section{Definition of the Layer for Estimates of $Q$ and $\underline{F_{h}}$}

For the upper boundary of the layer, for which $Q$ is estimated, we selected the depth $65 \mathrm{~m}$, chosen because this best determines the layer in which heat from the AW is stored and released (14). The depth of winter ventilation $H_{\text {vent }}$ is defined using an assumption that, starting from this depth, changes of water properties are not directly linked to the surface processes so that, for example, increase of depth of integration for calculation of $Q$ beyond $H_{\text {vent }}$ would not lead to statistically significant change of $Q$. Following this assumption, we calculated seasonal trends of $Q$ gradually increasing the thickness of the layer for which $Q$ is defined. Estimates of trends are shown in Supplementary Materials Table S1. Trends at the deepest layer, at which they are statistically different from the shallower-layer trends, are shown in bold.

Based on these estimates, we selected $130 \mathrm{~m}$ as the boundary of the winter ventilation layer. As Table S1 shows, the boundary of the layer at M3e mooring is deeper, at $\sim 150 \mathrm{~m}$. Therefore, our choice of $H_{\text {vent }}$ is conservative (i.e. estimates of heat fluxes $F_{h}$ derived from $\Delta Q$ would represent the lower bound) which is well justified considering the objectives of the study. Sensitivity of our estimates to the choice of $H_{\text {vent }}$ is evaluated 
660 calculating trends of $\Delta Q$ (and, therefore $F_{h}$ ) for $65-130 \mathrm{~m}$ and $65-125 \mathrm{~m}$ layers. These

661 estimates showed that the $5 \mathrm{~m}$ increase of the layer thickness increases $F_{h}$ by $9 \%$, which

662 may be considered as an acceptable range of uncertainty. Therefore, for all moorings $Q$

663 and their trends (and therefore $F_{h}$ ) are estimated using a $65-130 \mathrm{~m}$ depth interval.

\section{Supplementary Text}

665 Supplementary Materials References

666 51. V. V. Ivanov et al., Deep-Sea Res. I. 56, 1-14 (2009).

667 52. Polyakov, I. V. NSF Arctic Data Center. arctic-data.7792.16 (2016).

668 53. C. Torrence, G. P. Compo, Bull. Amer. Meteor. Soc. 79(1), 61-78 (1998).

669 54. G. Monterey, S. Levitus, S. NOAA Atlas NESDIS 14, U.S. Gov. Printing Office, $670 \quad$ Wash., D.C., 96 pp (1997).

671 55. P. Bourgain, J.-C. Gascard, Deep-Sea Res. I, 58, 745-756 (2011).

672

673

674

675 

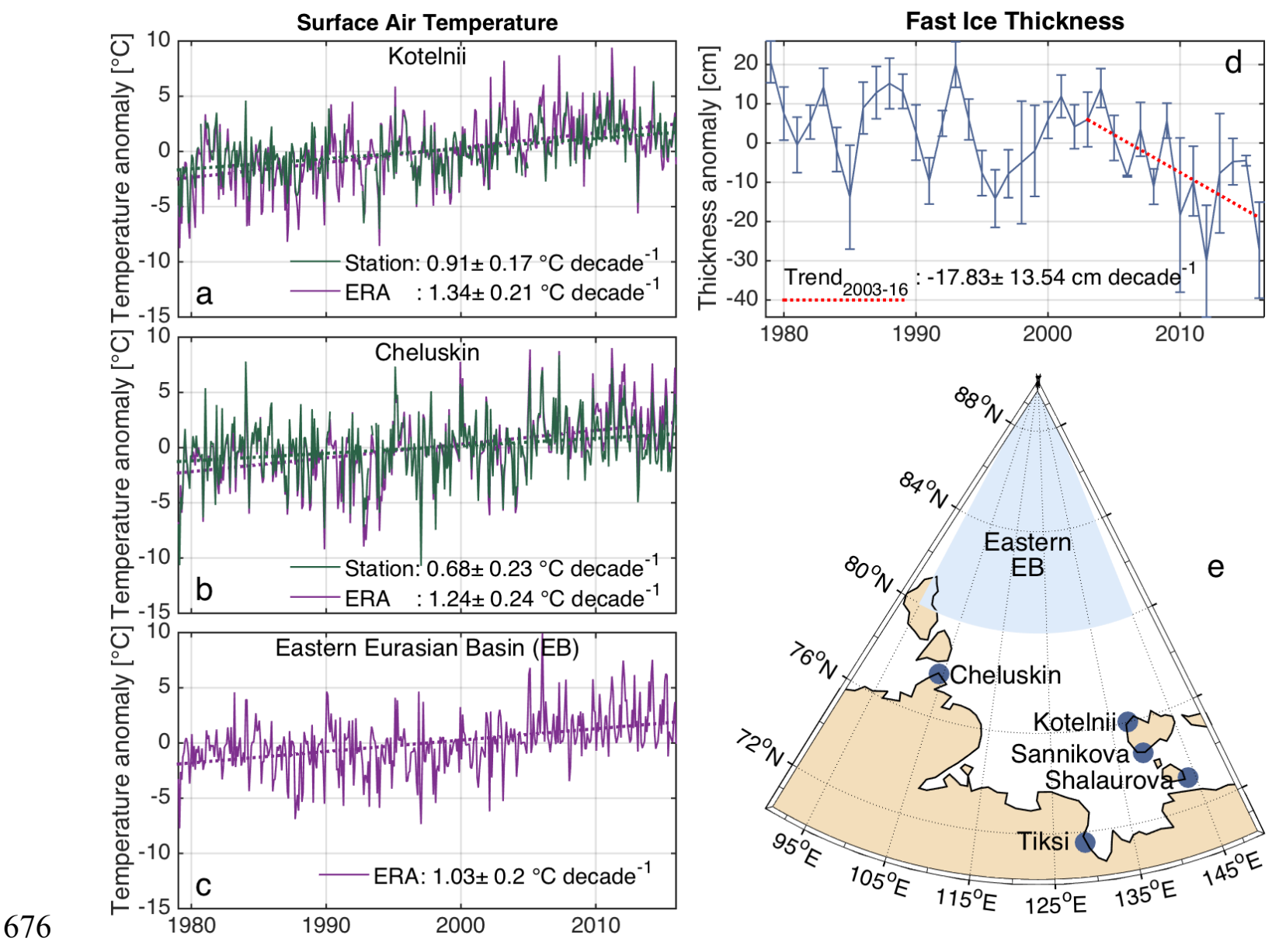

677 Fig. $\mathbf{S 1 .}$

678 (a-c) Monthly surface air temperature (SAT) anomalies $\left({ }^{\circ} \mathrm{C}\right)$ and their trends, from two 679 polar stations $(\mathrm{a}, \mathrm{b})$ and the ERA-Interim reanalysis product $(\mathrm{a}-\mathrm{c})$. (d) Fast-ice thickness 680 anomalies (cm) and their trend over 2003-2016, and (e) map showing locations of 681 stations providing air temperature and fast-ice thickness observations; blue color is used 682 to indicate the region used for calculation of area-averaged SAT time series for the 683 eastern EB shown in (c). 


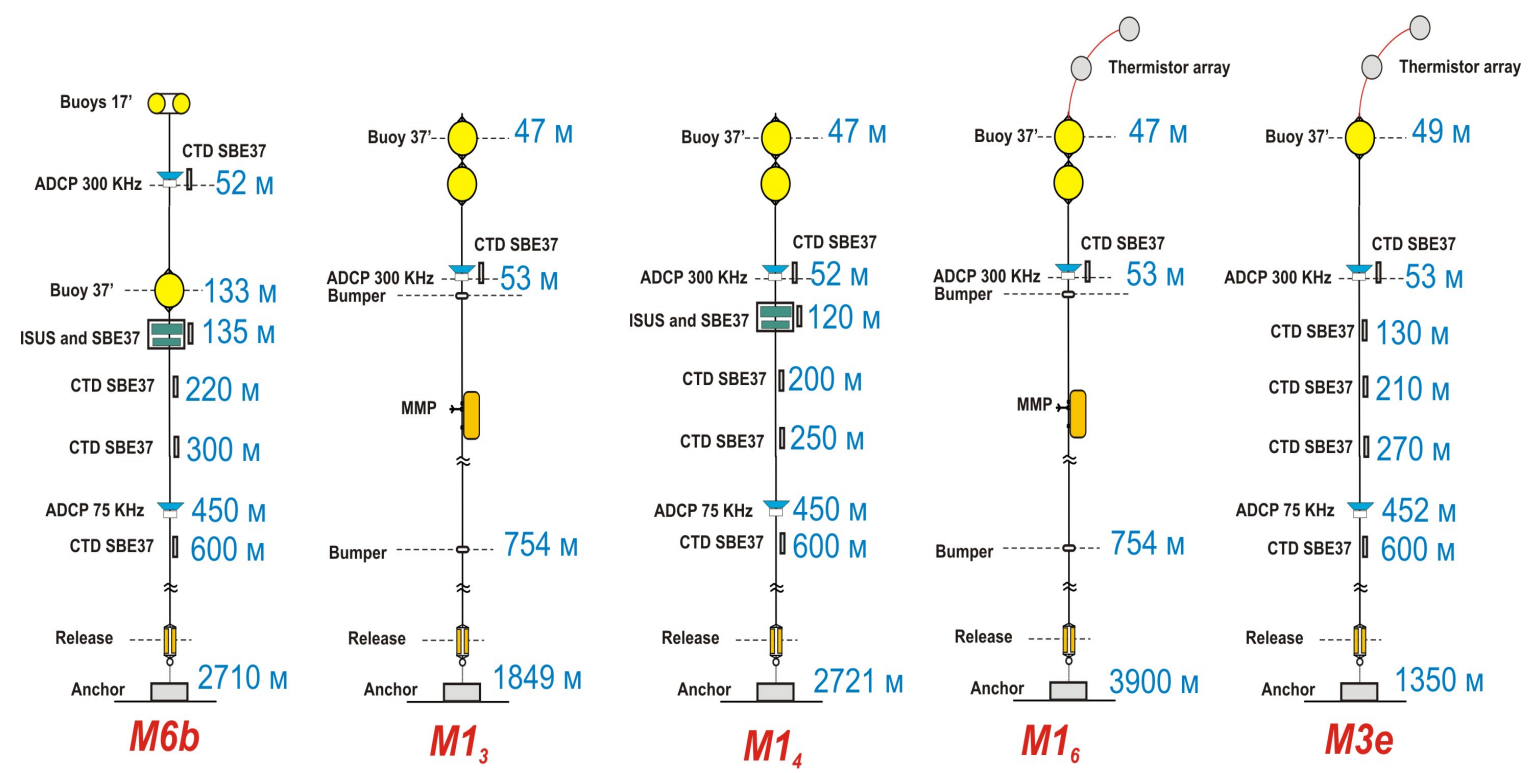

686 Fig. S2.

687 Schematics of moorings used in this study. Abbreviations used in this figure and relevant

688 to our discussions are: CTD = Conductivity-Temperature-Depth, ADCP = Acoustic

689 Doppler Current Profiler, MMP = McLane Moored Profiler. Thermistor arrays included

690 two SBE-37 and several SBE-56 separated by $2 \mathrm{~m}$ intervals and provided temperature

691 records only. 


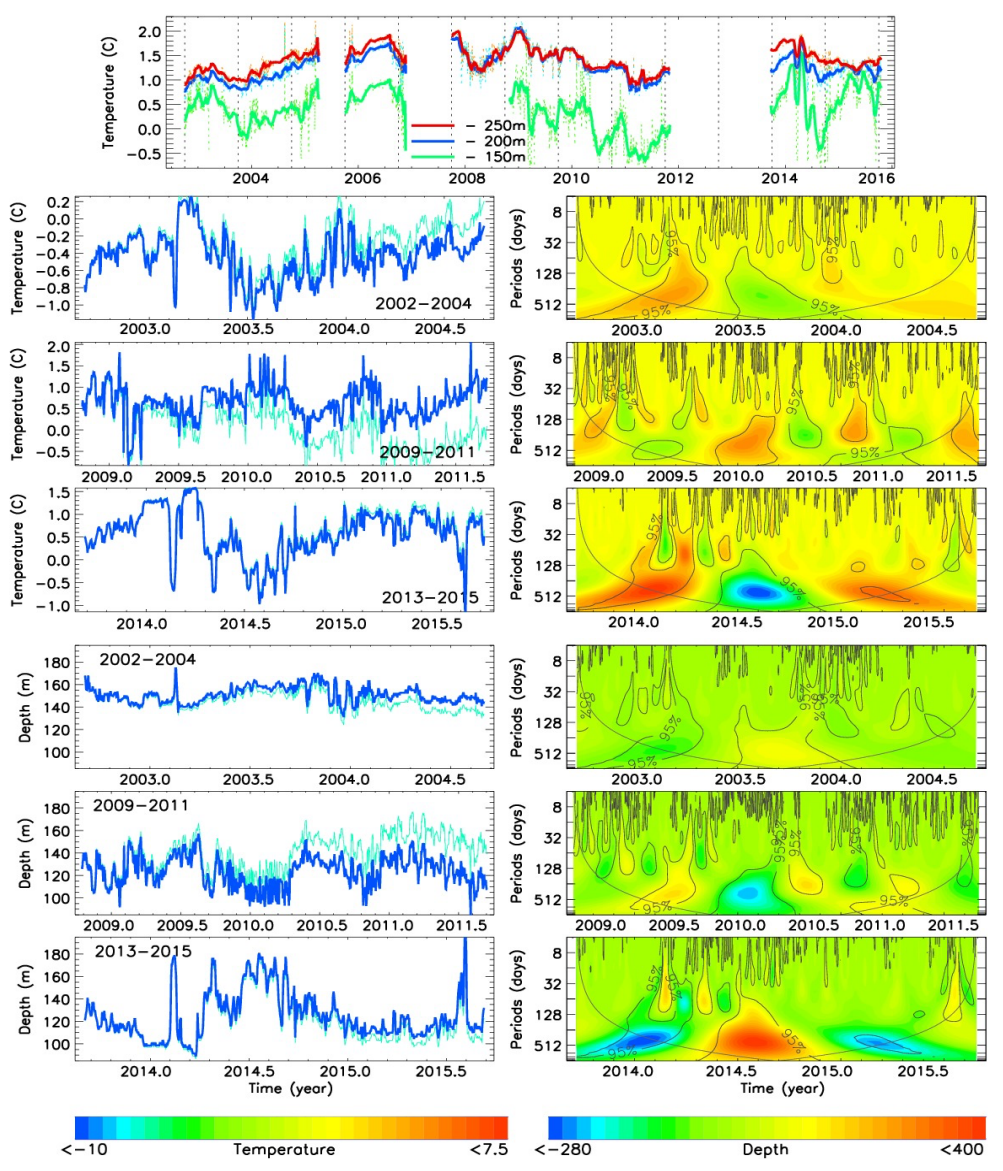

693 Fig. S3.

694 Time series and their wavelet transforms from the Laptev Sea mooring site $\mathrm{M1}_{4}$, eastern

695 Eurasian Basin of the Arctic Ocean $\left(\varphi=78^{\circ} 27.5^{\prime} \mathrm{N}, \lambda=125^{\circ} 53.7^{\prime} \mathrm{E}\right)$. In panels with

696 wavelet transforms, statistical significance and cones of influence are shown by grey lines.

697 (Top) Composite time series of water temperature at three depth levels. Dotted lines show

698 daily time series and solid lines show monthly mean time series. Note enhanced seasonal

699 signal in winters of 2013/14 and 2014/15. White segments indicate missing data. (Next

700 three rows) Original (light blue) and de-trended (dark blue) time series of water

701 temperature measured at 150m (left) and wavelet transforms of de-trended time series

702 (right). Note the strongest seasonal signal in the last two years.

703 (Bottom three rows) Original (light blue) and de-trended (dark blue) time series of the

704 upper Atlantic Water (AW) boundary (defined by $0^{\circ} \mathrm{C}$ isotherm, left) and wavelet

705 transforms of de-trended time series (right). Note: a) Strongly amplified seasonal signal in

706 the recent years and b) extreme shoaling of the AW layer in winters of 2013/14 and

$707 \quad 2014 / 15$.

708 

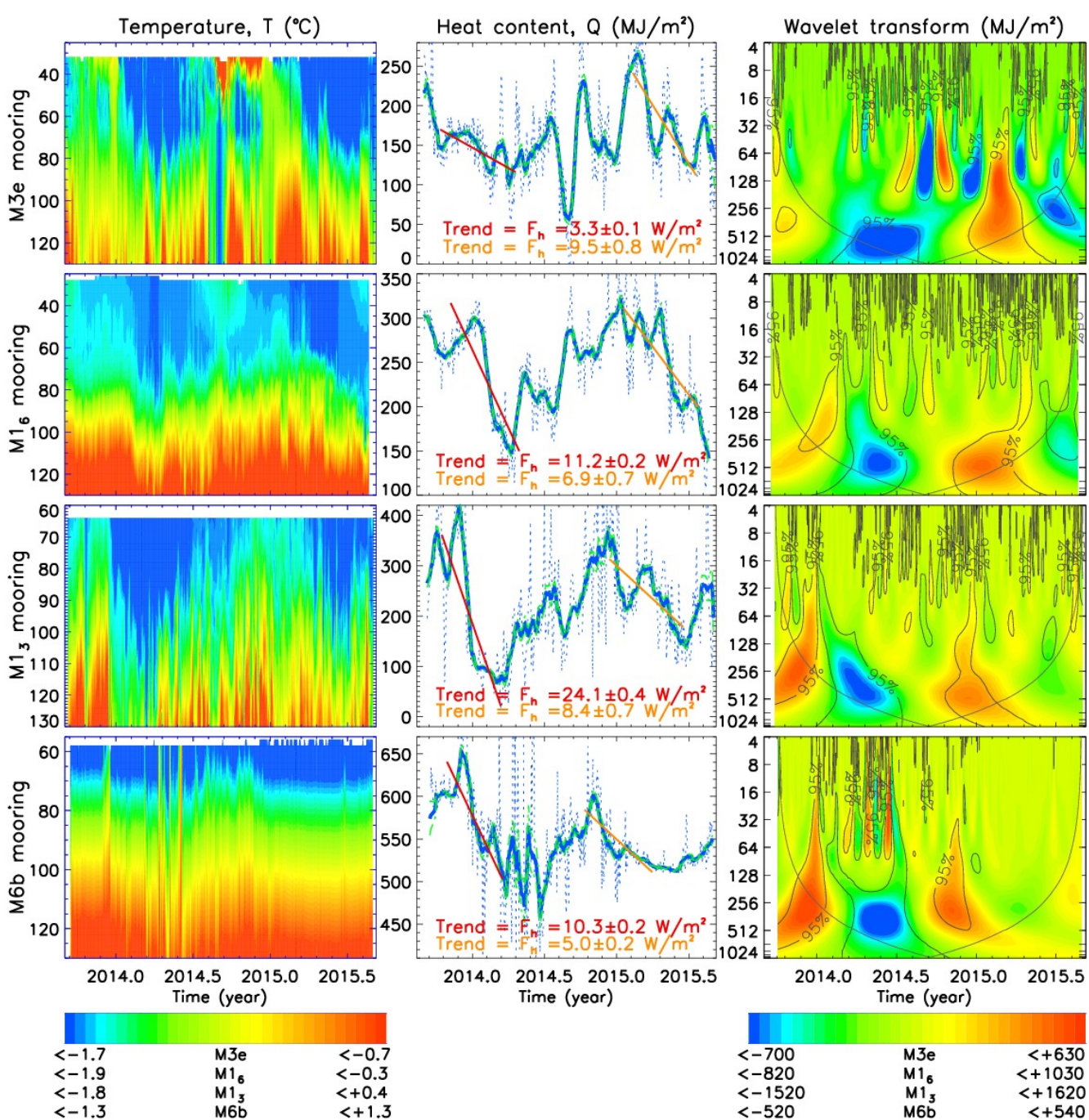

711 Fig. S4.

712 (left) Depth (m, vertical axes) versus time of water temperature, (middle) time series of $Q$

713 for the 65-130m layer (dotted blue lines show daily series, solid blue lines show monthly

714 means and green dashed line show standard errors) and (right) wavelet transforms of the

715 time series of $Q$ for four moorings. Maxima and minima of wavelet transforms were used

716 to define the boundary of winter seasons. These boundaries were used to calculate trends

717 of $Q$ shown by red (winter 2013/14) and orange (winter 2014/15) lines. Slope of trends

718 defines the rate of change of $Q$ in time, which is equivalent to the divergent heat flux $F_{h}$

719 (shown in red and orange). 


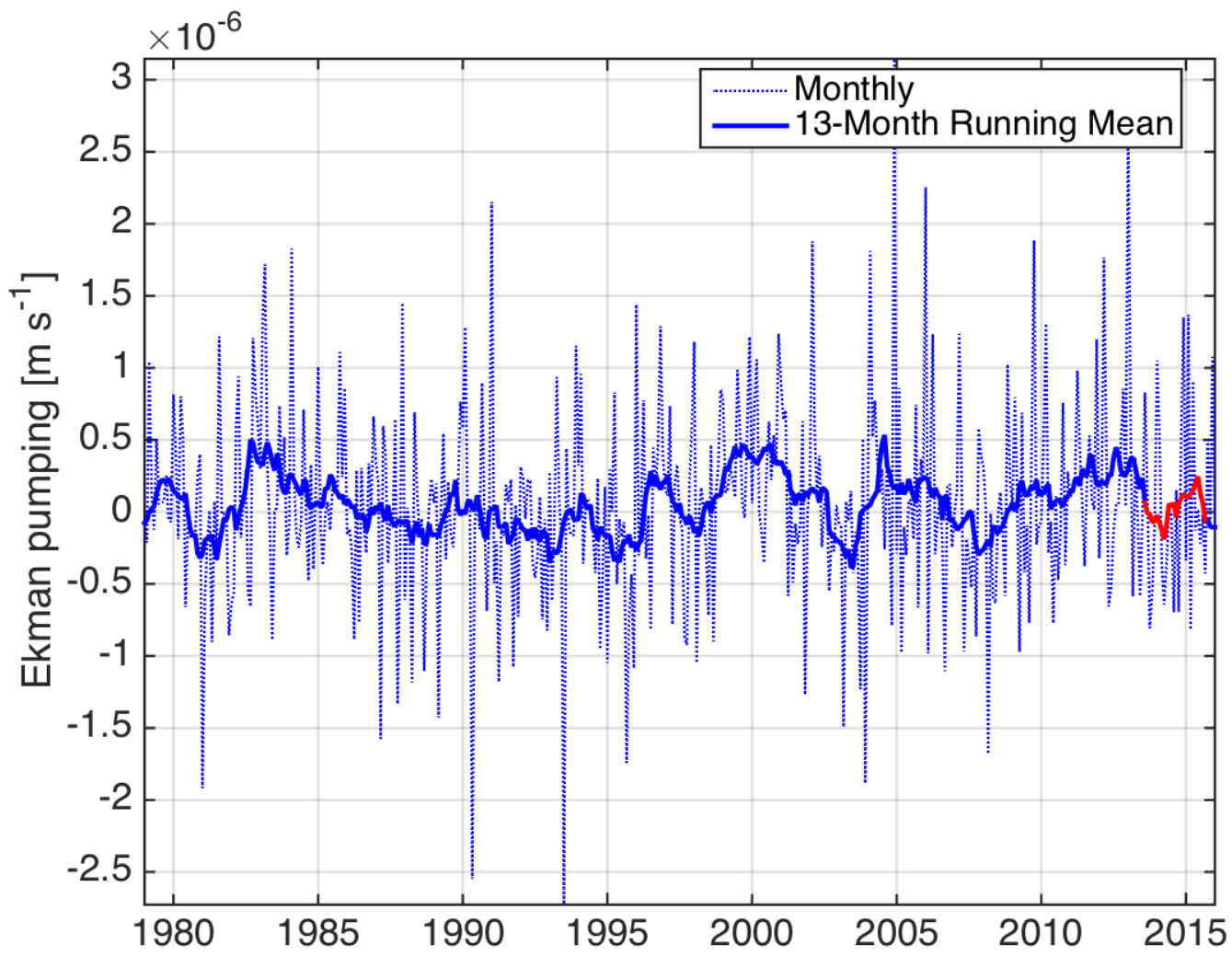

$721 \quad$ Fig. S5.

722 Time series of Ekman pumping velocity $w_{\mathrm{e}}$ averaged over the eastern EB of the Arctic

723 Ocean (see definition of the area in Supplementary Materials Fig. S4; positive is

724 upwelling, negative is downwelling). Red segment of the time series shows $w_{\mathrm{e}}$ for the

725 period of time covered by mooring observations; weak velocities suggest negligible role

726 of Ekman pumping in AW shoaling. 

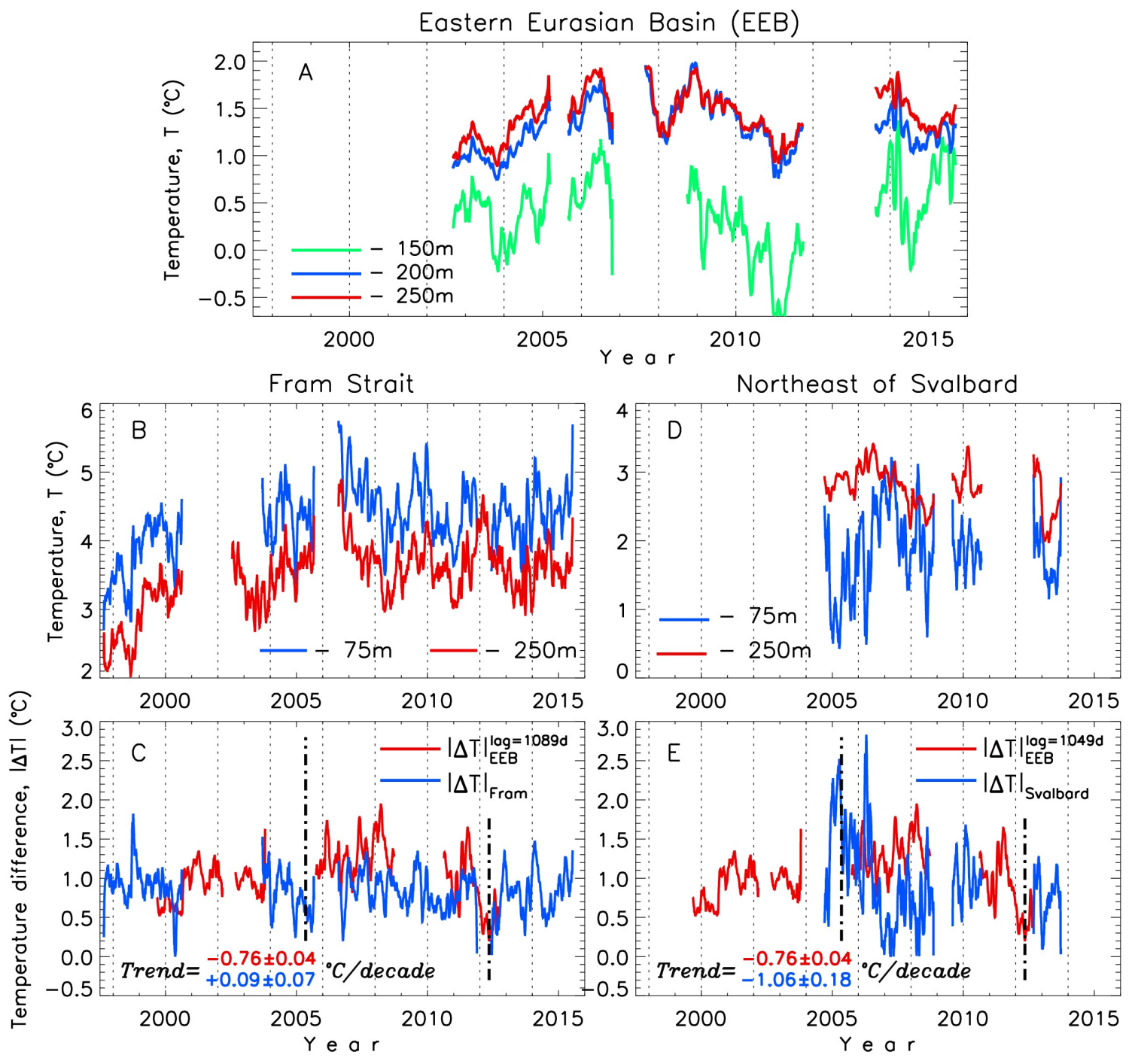

728 Fig. S6.

729 De-seasoned time series of AW temperatures $\left({ }^{\circ} \mathrm{C}\right)$ in the eastern EB (A), Fram Strait (B)

730 and northeast of Svalbard (D) smoothed using 30-days running mean smoothing window 731 and corresponding temperature differences $(\mathrm{C}, \mathrm{E})$. Vertical dash-dotted lines in $\mathrm{C}, \mathrm{E}$ 732 identify segments of the records corresponding to intensive loss of temperature contrast 733 between the upper and lower water layers; trends are computed for these segments. Lags 734 (C,E) are defined using correlation analysis. White segments indicate missing data. 


\section{$737 \quad$ Table S1.}

738 Estimates of winter $2014 / 15$ trends of $Q$ [ $\left[\mathrm{W} \mathrm{m}^{-2}\right.$ ].

\begin{tabular}{|c|c|c|c|c|}
\hline \multirow{2}{*}{$\begin{array}{c}\text { Layer } \\
\text { (meters) }\end{array}$} & \multicolumn{4}{|c|}{ Moorings } \\
\cline { 2 - 5 } & M3e & M1 $_{\mathbf{6}}$ & $\mathbf{M 1}_{\mathbf{3}}$ & M6b \\
\hline $65-100$ & $5.02 \pm 0.40$ & $3.95 \pm 0.38$ & $5.01 \pm 0.32$ & $3.68 \pm 0.15$ \\
\hline $65-110$ & $6.48 \pm 0.49$ & $5.03 \pm 0.50$ & $6.53 \pm 0.46$ & $4.30 \pm 0.19$ \\
\hline $65-120$ & $7.97 \pm 0.75$ & $6.07 \pm 0.61$ & $7.48 \pm 0.59$ & $4.73 \pm 0.22$ \\
\hline $65-130$ & $9.47 \pm 0.75$ & $\mathbf{6 . 9 0} \pm \mathbf{0 . 6 9}$ & $\mathbf{8 . 3 9} \pm \mathbf{0 . 7 4}$ & $\mathbf{4 . 9 8} \pm \mathbf{0 . 2 5}$ \\
\hline $65-140$ & $11.00 \pm 0.91$ & $7.52 \pm 0.75$ & $8.91 \pm 0.87$ & $5.16 \pm 0.28$ \\
\hline $65-150$ & $\mathbf{1 2 . 4 3} \pm \mathbf{1 . 0 5}$ & & & \\
\hline $65-160$ & $13.45 \pm 1.17$ & & & \\
\hline
\end{tabular}

739

740

741 